第 2 巻第 3 号

行

な 明

つ治

て 五

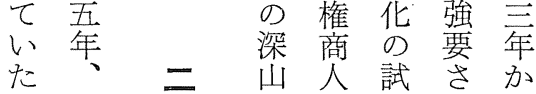

土信二山人試さか

J

橋 州

半上深

田でみれら

製あでた始

系りあわあ

快

野

蔵 諏

家无訪

で字

田場、、㤎ら

思製場当た国れ

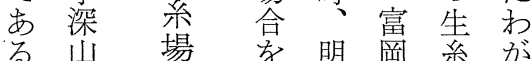

。田設中治製生国

小立心政䒺産の

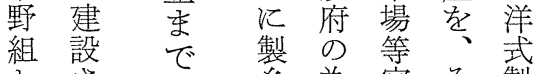

とさの系為官々 製

交机業替立の系

涉る去近方製粗器

を小橋代を系製械

も野家化つ場監の

組に学々可造移

以深つめめ他を植

前山いぐ、沙克は

土製

橋萣場

は の

文世話

政 方

の と

頃 な

半の

蔵は

の同

父地

半で

兵 醸

衛造

の業

代 並

か び

ら

度糸

々 問

冥剭

て 方洋し開

洋生式、港

式系製大以

製貿糸量 後

系易器に突

器学械乙如

械盛の 文

移に移もし

植 行 植 優

のなに良開

問っ積斉少

題て 極—れ

学い的比 た

考た芯行外

察小专な国

乙野つ5市

た組たべ場

いでのくへ

L"

組

b

深

V

山

外田

国製

械 贫

植埸

D 0

側 権

面営

之あ澺向

思口、図汗

う。幕されて

以期た量屋

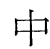

本才

秀

、幕系る 
経 営史 学

送呈 卆曾記と

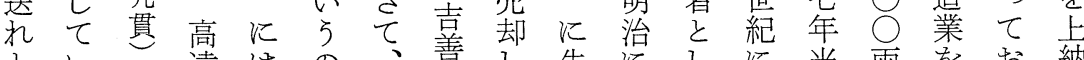

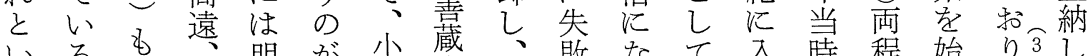
いる

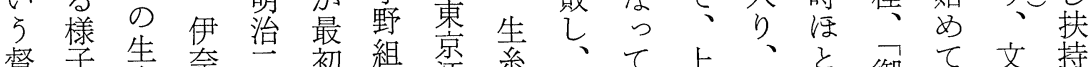

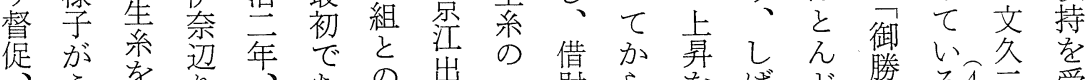

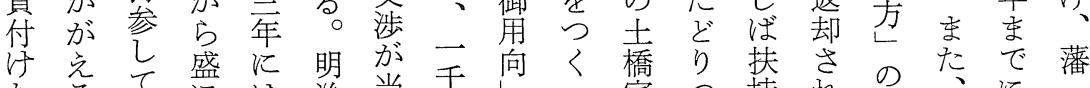

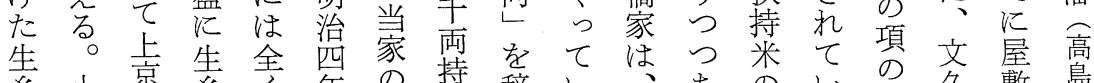
系小野し 系交年

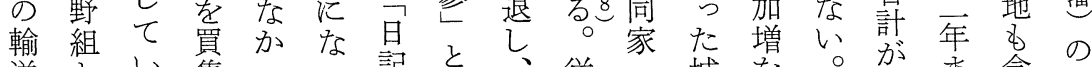

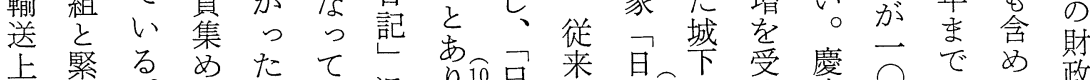
上緊る 手な密東いで急現、管釀記特藩年六に、侖に

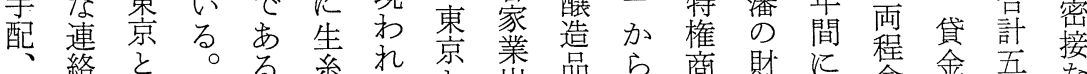

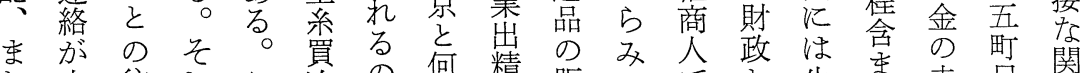
た交往しこ次の何精販るでと生ま足関

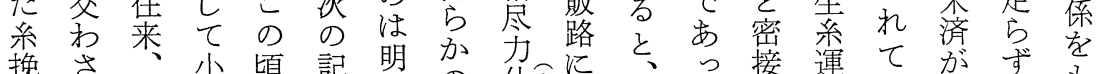

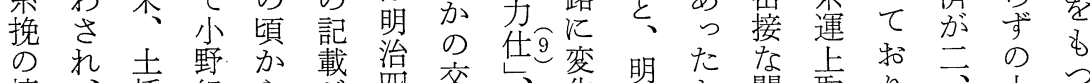

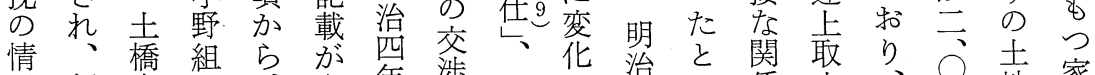

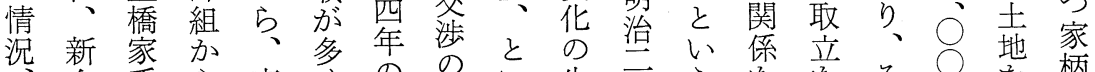

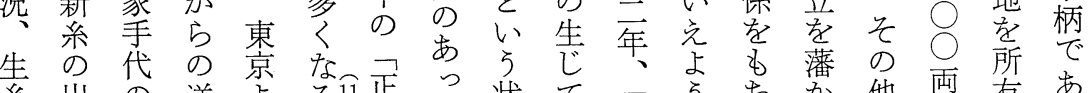

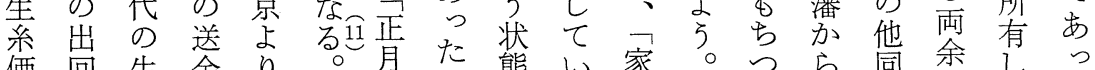

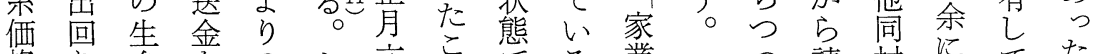

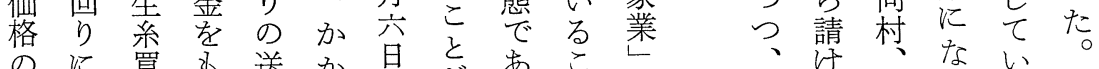

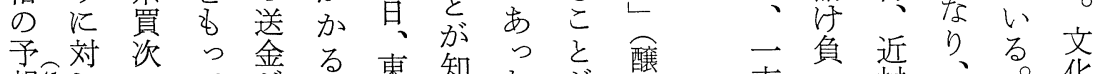

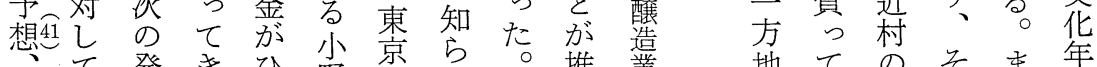

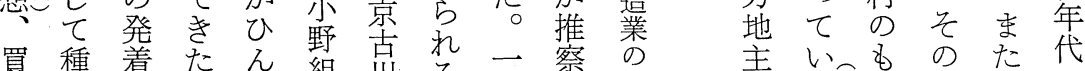

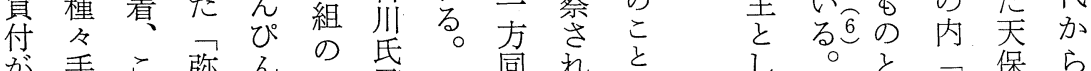

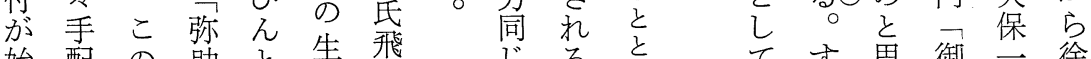

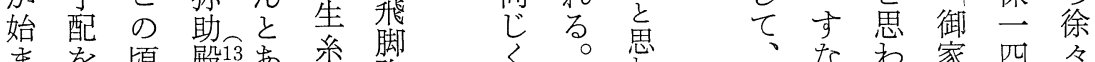
まを 頃殿13

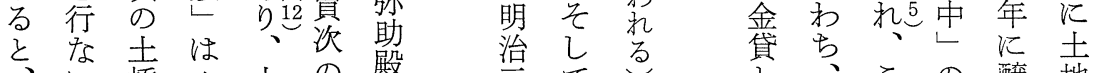
そい橋士 去 の の資は 個家載時 - 家 資金活個では時一他 、家金合を積

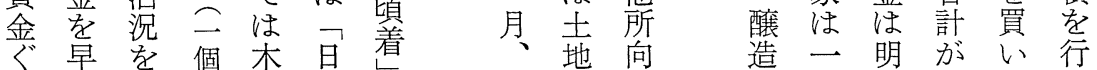


第 2 巻第 3 号

2 下ををに人で失は 巻た利所々は方土

土点明用蔵乞同机橋私

橋に治すさて家て保が

家紹五るれのか特雄利

文介、以て活

書さ六外い動発、でし

机年にたを見特あた

御て梁なる示さにる土

扶い山かのす扎貴。橋

持る田っを史な重信家

方同製たみ料か史濃の

被家糸。る等っ料濃史

仰の場しをあたと䖝料

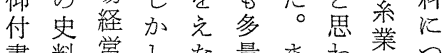

書料営乙た量ま和業つ

。当幸のにた机い

利時いで所深る车て

用土深蔵山田尔野言 た橋山て㧈製野村す

家田、て系器誌る

の製旦い場械に当

支場類由係記記時

をのにで以記載の

示収しあ外吕さ士

す支てるの口橋

帳を多方同明て半

面示手、家蛹い蔵

類す紙この手る家

表類れ幕巻同は

発やに梘撃家

さ挽てと明請蔵在

れのもん治取のや

た状連ど初通深は

況続処年亡山り

そを—分の等田同

の予貫さ豪製製地

他測乙れ商系系上

平したてと場場諏

平 5 野和䢖関訪

野るのり想設係に

村㧪は、像にの在

誌子な的さ関史住

下表くずれす料で

下な断かるるは醉

卷ぞ続に大史惜造

ᄀが的、規料し業

信発偶し模はいを

濃見然かな、営

龺さ的も城私と文

系秋な偶下のに

業た。然町調多当
上以動 験翌 挽兵こ咅り、 訪上治回衛の拜 に一五の支様な系 深簡の土年一配にか価 山単打橋、策人、格 田に開家小とた明た包の 製明へと野しる治。騰 系治のし組て、小四落 場四動ての、野年 設年きは世時組頃品 立、、か話の采吕質 のす 史な先大方 5 の プな 料り と商㤎小野 出

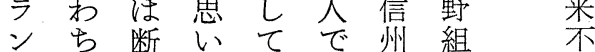
が深続切深 あにの出 実山的っ山り積為来

現田なた田為極替等15 製 が 転 製替的方 詳 る系ら換 采方なと細 こ場々を場で進して と設の計を出て 連 に立こつ設あをの絡 な前とた立っ行巨音落 る年をと守たな大 でし示学学野て 無 れ のてる至組い利て 橋 る 家。末 劳 に開スで分本 港はのるるを か W 加、生 が流尚

て 5 そ系士用

の 明れ買橋し べ治ま次家ら

た初でと沈る 年生 W 前 特

加媇了述、権

か か 製手のの

る村造段ご取

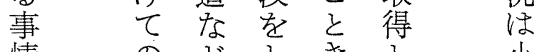

情

背
のどときと少

橋くたき行を組

景家行 の かしの

にのなでけでな 要

し経っあた、請

て 済た た 家 古経 5 運河 答
土全っ傾平野 


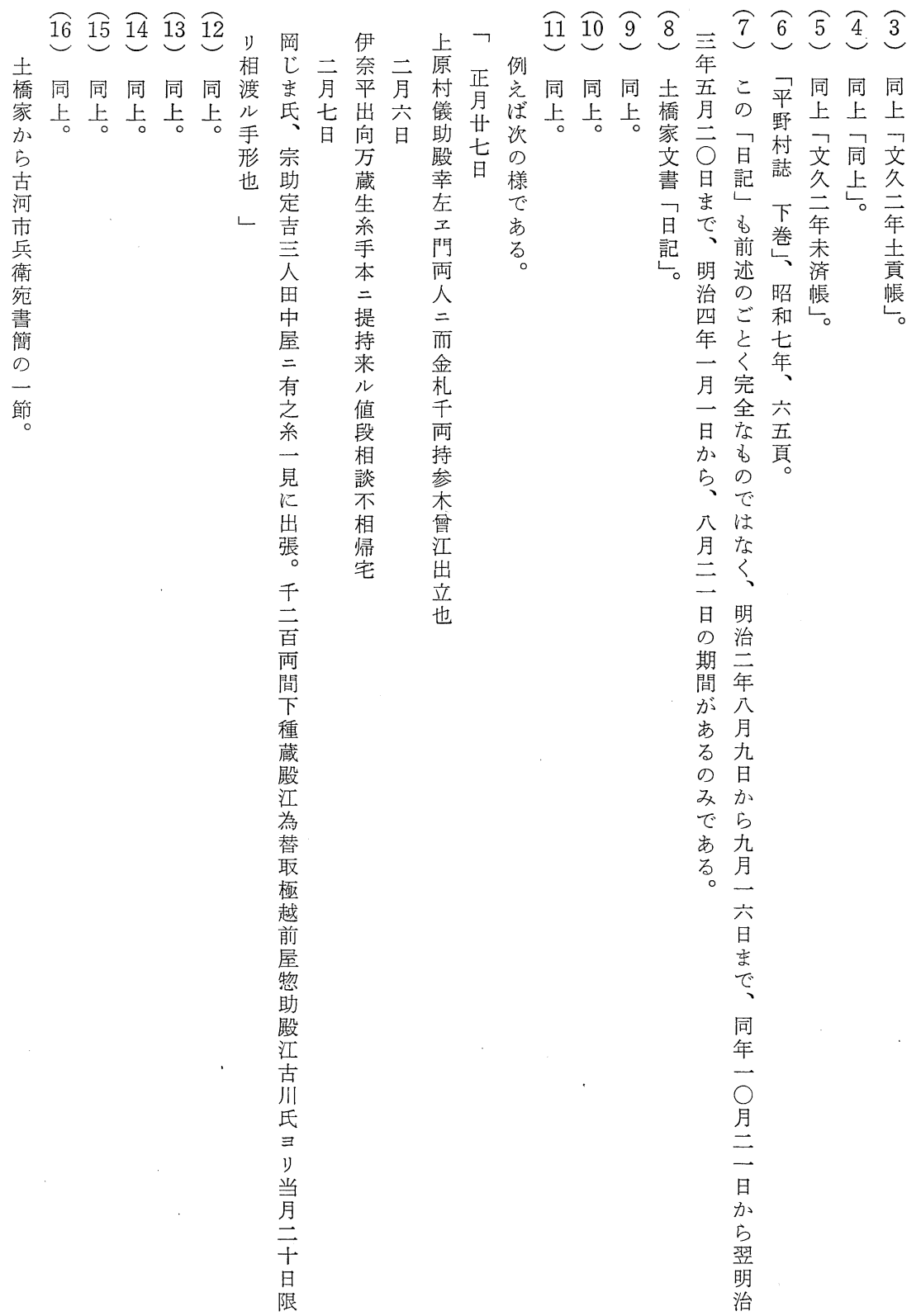


第 2 巻第 3 号

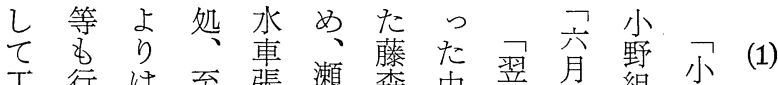

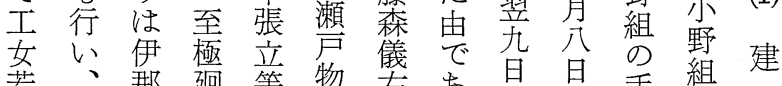

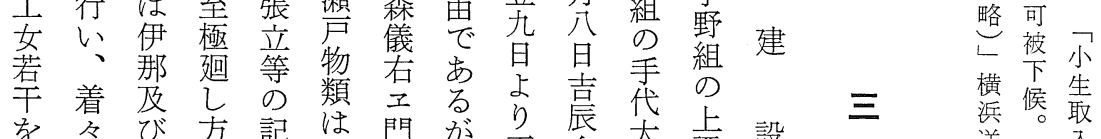

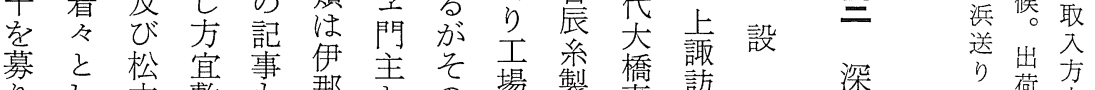

り乙乙 本 敷 も 那

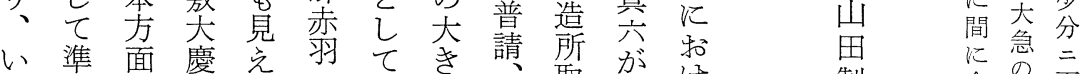

よ備よ存てへ、学器取当け

〈 終 蛹候等

繰つ続と築㣫不器橋来系

業た な

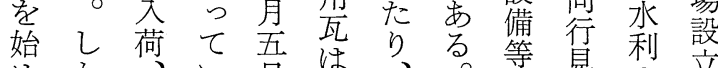

めか、心 日 神、者。分の竞

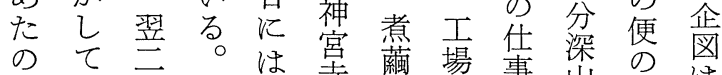

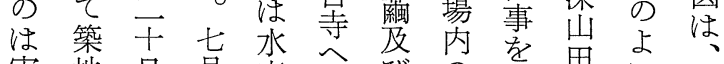

実地日月車、びの進治い明

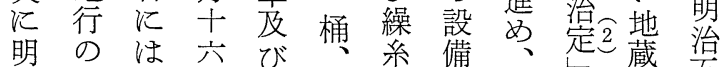

治伝製日枠笑の施飞六年

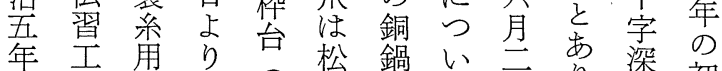

分女水は初本鍋市云り、染初

月の試義はへ松は三田頭

二中験右直、本、百江出

十六、繰其銅やに敷既

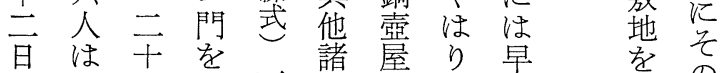

の六二主部方市こ望決 前

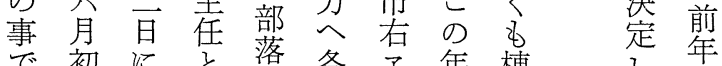

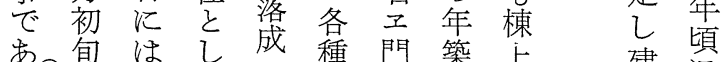

あ旬 は乙成種門築进它

る3帰 春て 只用 及 地 そ

更し蛹视前の大見っ 始た

に来、築前該和学て

九 た 夏立少文村 の

月の蛹着く祭め銅た る

思製急急盆

系专被思

場当相召

の当聞宣

設筑当様

立生咅御

そ 系主

の の糸買縮

崩嘅恷,

面分 リ

学 二 奉

語御存

乙座 候

七候無

間油

る 仕断

揚 是

手迄

間的

取 精

机名

申 仕

候 候

精 得

々 共

取 荷

急 数

出 無

荷之

候 事

間 故

不 無

悪 拠

御御

承 儀

引 此

可段

被 不

下悪

候御

炃聞 
経営史学

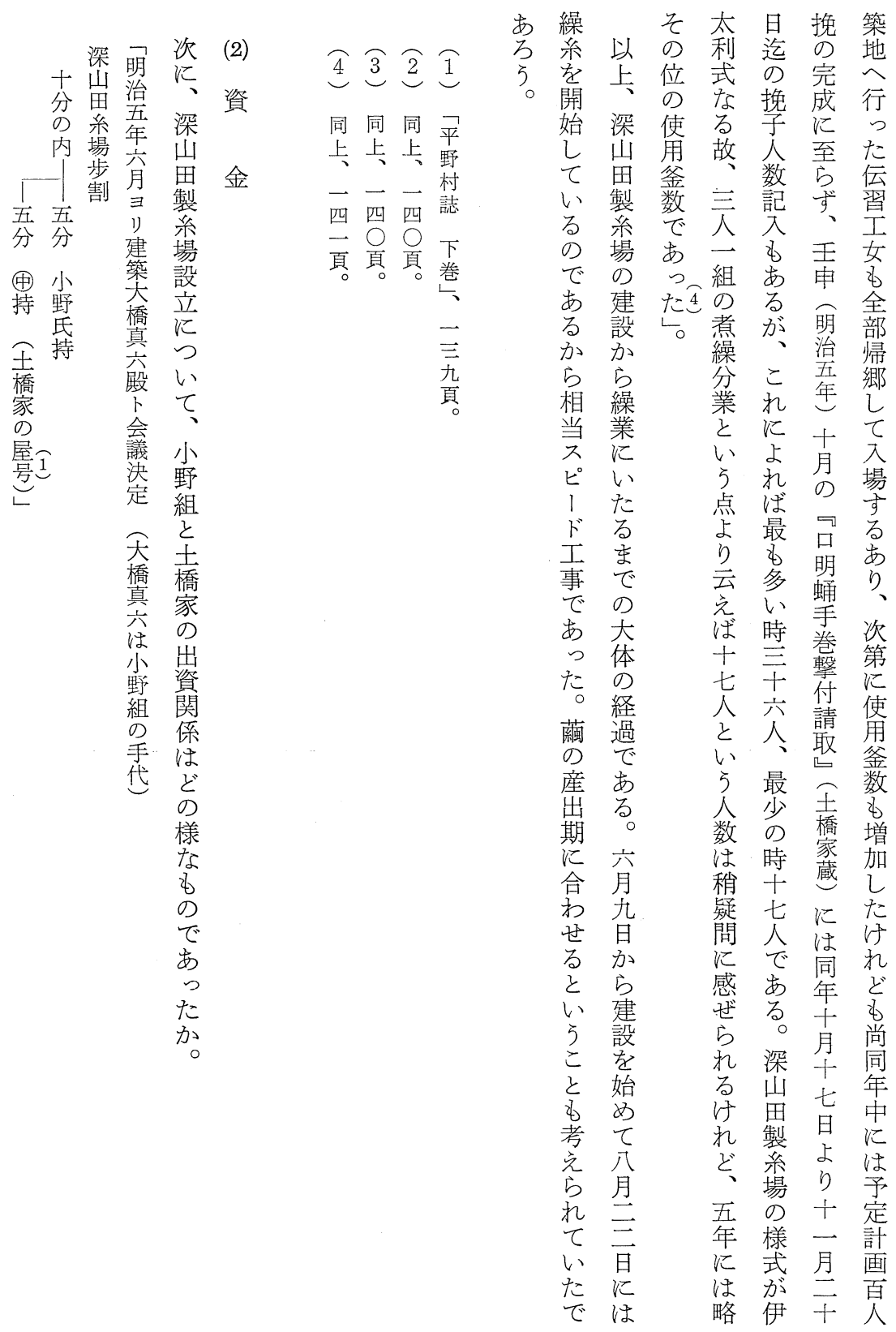




\section{第 1 表}

\begin{tabular}{|c|c|c|c|c|c|c|c|}
\hline \multirow{2}{*}{\multicolumn{2}{|c|}{$\begin{array}{l}\text { 明治 } 5 \text { 年諏訪器械糸発 } \\
\text { 行以来入用金仕払 } \\
\text { 水車諧材木 } \\
\text { 鉄釘大手 } \\
\text { 間 }\end{array}$}} & \multicolumn{2}{|c|}{$\begin{array}{l}\text { 左段ノ内蛹我系婏 } \\
\text { 金利等引去リ水車 } \\
\text { 建家器械入用金 }\end{array}$} & \multicolumn{2}{|c|}{ 器械注文仕継 } & \multicolumn{2}{|c|}{ 諸道具買入継 } \\
\hline & & & $\begin{array}{l}99 \text { 円永 } 68 \\
7 \text { 文 }\end{array}$ & 3 銅鍋 12 & 100 円 & 膳椀拭巾等 & $\begin{array}{l}9 \text { 円 永 } 250 \\
\text { 员 }\end{array}$ \\
\hline $\begin{array}{l}\text { 建家諸材木 } \\
\text { 諸㭀鉄釘大 } \\
\text { 工手間其外 } \\
\text { 費 } \\
\end{array}$ & $\begin{array}{l}511 \text { 円 永 } 57 \\
\text { 文4分 }\end{array}$ & & $\begin{array}{l}511 \text { 円永 } 5 \\
7 \text { 文4分 }\end{array}$ & $\mid \begin{array}{l}\text { クト築立上 } \\
\text { 塗左官石 } \\
\text { 灰苧苆 }\end{array}$ & $\begin{array}{l}47 円 \\
1 \text { 分 }\end{array}$ & 鍋釜飯針類 & 4 円永 7 \\
\hline $\begin{array}{l}\text { 器械鉄物金 } \\
ク \text { ド瓦 }\end{array}$ & $\begin{array}{l}621 \text { 円永 } 5 \text { 文 } \\
7 \text { 分 }\end{array}$ & & $\begin{array}{l}621 \text { 円永 } 5 \\
\text { 文7分 }\end{array}$ & 鉄細板鉄陶 & $\begin{array}{l}21 \text { 円 永 } 375 \\
\text { 文 }\end{array}$ & 5 傘下䭾 & 6 円永 500 文 \\
\hline 䒺挽立入用 & $\left|\begin{array}{l}111 \text { 円永 } 833 \\
\text { 文9分 }\end{array}\right|$ & & & $\begin{array}{l}\text { 器械鉄物二 } \\
\text { 式但 } 1 \text { 人挽 } \\
1 \text { 画 } 1 \text { 分 }\end{array}$ & $\begin{array}{l}28 \text { 円 永 } 332 \\
\text { 文 } 2 \text { 分 }\end{array}$ & 2 下駄棚蛹棚 & 1円永541文 \\
\hline 飯費 & $\begin{array}{l}96 \text { 円 永 } 353 \\
\text { 文2分 }\end{array}$ & 上4分, 1 & $\begin{array}{l}24 \text { 円永 } 18 \\
\text { 文2分 }\end{array}$ & $\begin{array}{l}\text { センマイ木 } \\
\text { 地刻共 }\end{array}$ & $\begin{array}{l}9 \text { 円永 } 979 \text { 文 } \\
1 \text { 分 }\end{array}$ & 空ラ空水コ & $\begin{array}{l}2 \text { 円永 } 879 \text { 文 } \\
\text { 2分 }\end{array}$ \\
\hline 炭薪油 & \begin{tabular}{|l|}
74 円 永 429 \\
文2分
\end{tabular} & 上5分， 1 & $\mid \begin{array}{l}14 \text { 円 永8 } \\
85 \text { 文8分 }\end{array}$ & $\begin{array}{l}\text { 籠七小目籠 } \\
\text { 水溜大桶小 } \\
\text { 桶大柄杓共 }\end{array}$ & & $\begin{array}{l}\text { 揚枠干シ火 } \\
\text { 針大小紙張 } \\
\text { 立共 }\end{array}$ & 10 円 永 577 \\
\hline $\begin{array}{l}\text { 住居建継用 } \\
\text { 意古建具買 } \\
\text { 入其外前貸 } \\
\text { 共 }\end{array}$ & $\begin{array}{l}28 \text { 円 永 } 441 \\
\text { 文1分 }\end{array}$ & & & $\begin{array}{l}\text { 器械取付大 } \\
\text { 工煙抜瓦卜 } \\
\text { 乇 }\end{array}$ & $\begin{array}{l}15 \text { 円 永 } 479 \\
\text { 文1分 }\end{array}$ & $\begin{array}{l}9 \text { シケ糸引道 } \\
\text { 具 }\end{array}$ & 永350文 \\
\hline 炊き月給 & 18 円永50文 & & & \begin{tabular}{|l} 
水湯抜樋埋 \\
手間煙抜瓦 \\
卜モモ
\end{tabular} & $\begin{array}{l}6 \text { 円永 } 966 \text { 文 } \\
7 \text { 分 }\end{array}$ & 夜具㴤 & 18円 \\
\hline 夏虫蛹買 & $\mid \begin{array}{l}935 \text { 円永 } 968 \\
\text { 文8分 }\end{array}$ & & & $\begin{array}{l}\text { 揚枠 } 120 \text { 結 } \\
\text { 縄共 }\end{array}$ & $\begin{array}{l}30 \text { 円 永 } 325 \\
\text { 文 }\end{array}$ & 5 蚊帳 & 7円永 250 文 \\
\hline \multirow{2}{*}{$\begin{array}{l}\text { 借り入口に } \\
\text { 金利 }\end{array}$} & \multirow{2}{*}{$=\begin{array}{l}121 \text { 円永 } 901 \\
\text { 文6 分 }\end{array}$} & \multirow{2}{*}{$\begin{array}{l}\text { 蛹代金金 } \\
\text { 利引テ }\end{array}$} & \multirow{2}{*}{$\begin{array}{l}44 \text { 円永 } 46 \\
4 \text { 文1分 }\end{array}$} & \multirow{2}{*}{$\begin{array}{l}\text { 針鉄火䈉十 } \\
\text { 能鍋蓋小 } \\
\text { 其他小物 }\end{array}$} & \multirow{2}{*}{$\begin{array}{l}10 \text { 円 永 } 266 \\
\text { 文6分 }\end{array}$} & 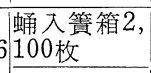 & $\begin{array}{l}345 \text { 円永 } 332 \\
\text { 文3 分 }\end{array}$ \\
\hline & & & & & & 住居建継 & 330 円 \\
\hline 総計 & $\left|\begin{array}{l|}2,618 \text { 円永 } 7 \\
27 \text { 文9分 }\end{array}\right|$ & \multirow{2}{*}{\multicolumn{2}{|c|}{ 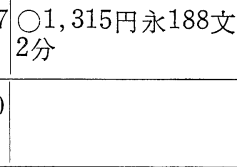 }} & \multirow{2}{*}{\multicolumn{2}{|c|}{$\bigcirc 283$ 円永 803 文 9 分 }} & \multicolumn{2}{|c|}{$\bigcirc 736$ 円永 431 文 2 分 } \\
\hline \multicolumn{2}{|c|}{$\begin{array}{l}\text { 上糸器械入用引テ } 1,30 \\
\text { 3円永539文 }\end{array}$} & & & & & $\begin{array}{l}\text { ○印総合 } 2, \\
\text { 文 } 3 \text { 分但総 } \\
\text { 共百人挽全 }\end{array}$ & $\begin{array}{l}335 \text { 円永 } 423 \\
\text { 器械家雑具 } \\
\text { 備ノ積 リ }\end{array}$ \\
\hline
\end{tabular}


経 営 史 学

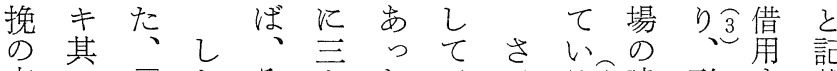

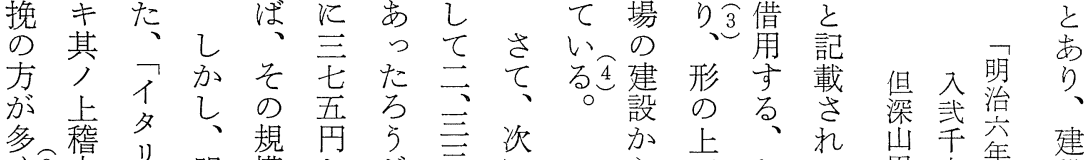

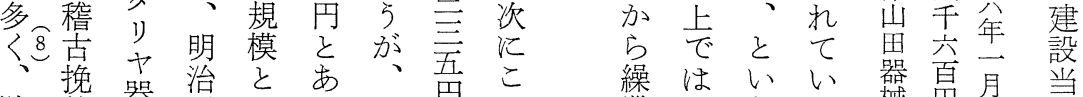

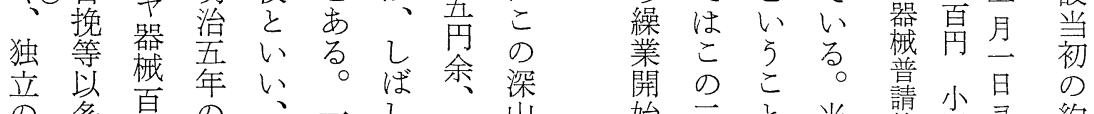

の多百の、一し子山

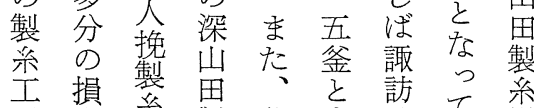

場失采製 釜求地て 場

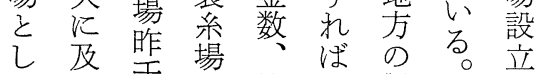

て候毛挽一製官の

の $\vdots$ 六 前子釜采官費

運就公 記 数 豆 業 虽 角

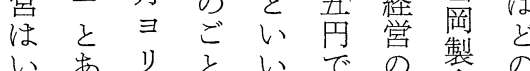

まり造々全当事系位

た、立婏く時例場で

軗明相子当と治建亦

道治始一時し出設さ

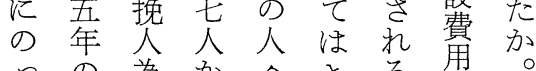

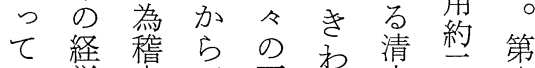

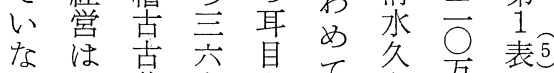

な は克六貝めて令方表方

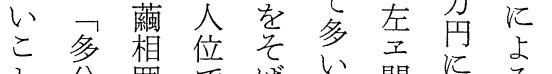

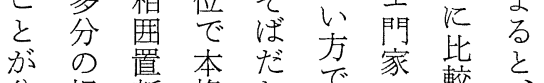

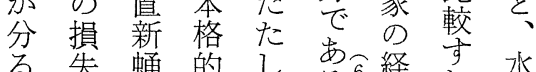

る失蛹的しめ経学 水

でで来活た と活動こ律

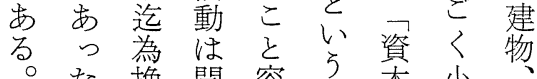

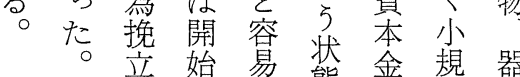

し年㛎易態金規器

加 和 5 比な道

も越なな比治簡具

始二と当 等 野严約

後六で時年氐恶

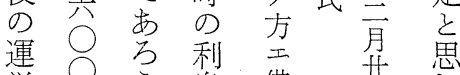

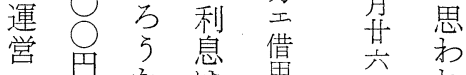

切学架梠角公机

哇野結厘著检 る

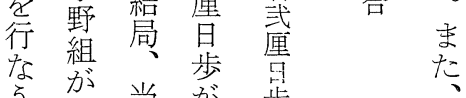

こシがず較十単類

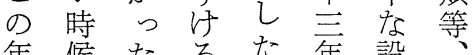

年候たるた年設

はに。店資備合

方党唯步

賃肖蓑

ら料で計

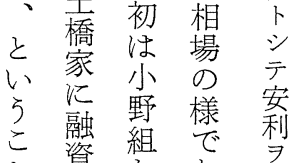

こ 融 組

でする る

ある、三市用

た 六ら の

明家品厘 話

治ば円安穴

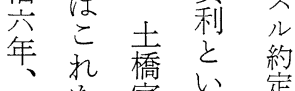

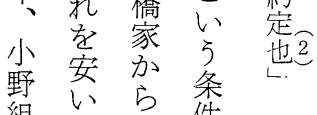

組利 5 件

は梨、で

さ志元 去

ら借尣橋

り円䧇

七受の小

壮出 野

$\bigcirc$ 資 組

深 と 加

円山なら

融田っ資

資製て 金

乙系踏学 
第 2 巻第 3 号

始と

め市

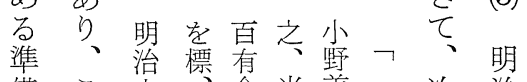

備こ六年当常普次治

整願四重之蛹手明年

些顥月柄幅産代治の

、寄湊出大橋怎六繰

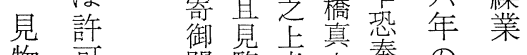

物可聞覧者六奉の

人に上忘盛申願深

やな 可立に談上山

製つ被入换只田

絃てょ市旁立生䒺書製

場 い真雑理イ系系

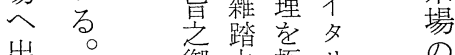

出口御总極り状

の粗許限粗苛㭠 洗

工製 喜可製热觉

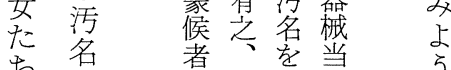

ち名者取脱郡当年

な脱立鎮望下

ぞ脱紊候桑

で候学権漛原

雑様男力只村

踏々 鼻警䓌登

る製締外願行

た製美失候試

め場響多得験

官荡 意難共精

許建舟語製

乙設奉痛弥仕

いの 存心全先

万貝候夏般

札的候人御

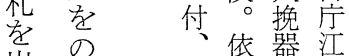

出べ此䕍械实

さべ段右成入

乙、御登功御

て い 聞行总覞

れい竞義卡候

とよ程御者通

心百仰済若嵒

○人願以乭柄

て婏候。官要三
あ木

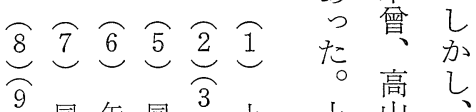

9 同矢同 $\overbrace{3}^{3} \pm$ 橋

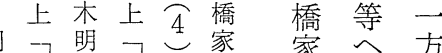

上元夫生文家 買方

方我系同書收当

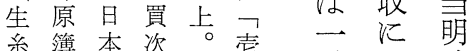

買㜑近挽番五㧤治

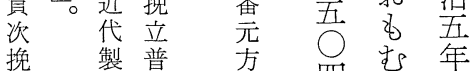

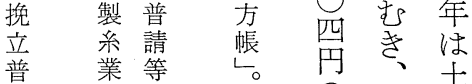

請少

等 成 表

表立占。

ᄂ 昭

和

三

年

示
九
頁

ウ 吉

買䛠家

料三

を五前

乙二年

以貫

る る 堌

生 乙

等 規

買 模

付な

た野

そ組

れ生

情采

二 買

五を

三 行

二な

- $\tau$

円 いล

余要

子 諏

の 訪

ぼ

る伊

額 奈 


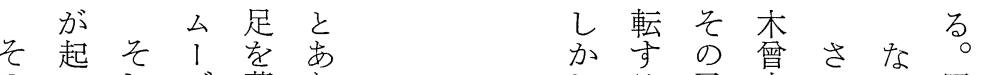
清就の つし ズ惹り、察業買最、る予方て、扰同 算而上てて、起、被三先最、た想面、、年

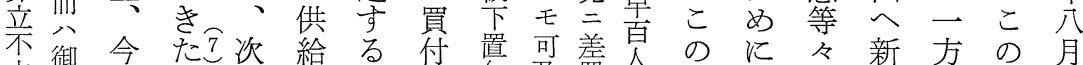

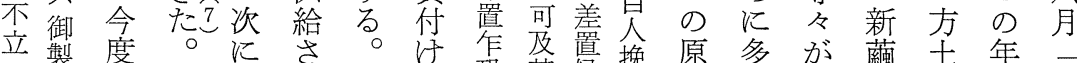

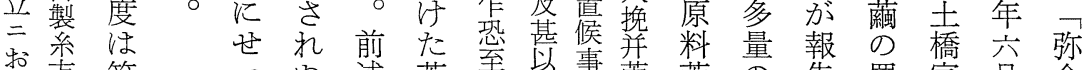

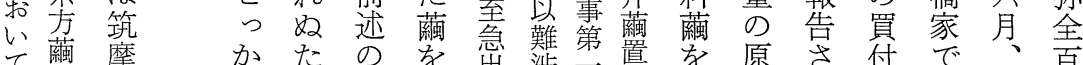
て藏摩かたの省出渋第置原さ付で、百

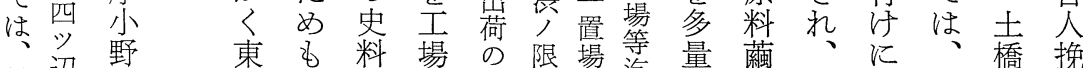

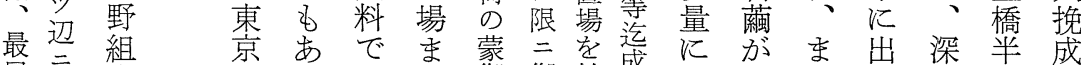
早而支築つ賃で御御茂功し必た か山蔵功 年店地た挽運許座総云加要深汀田は仕

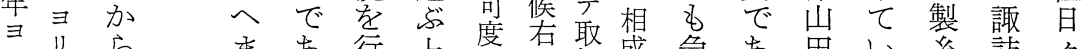

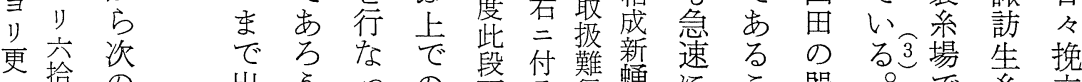

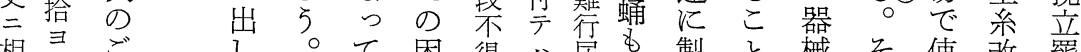

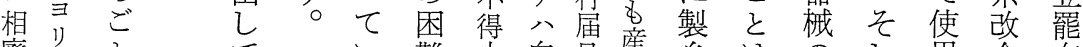

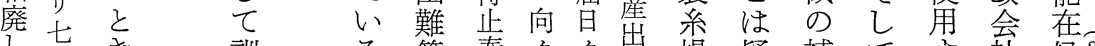
可拾 書 訓 る 等奉多出場 疑 補て 主 社候

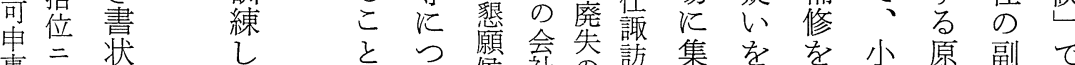
事二状々つ原会社の訪集を学 小原副で

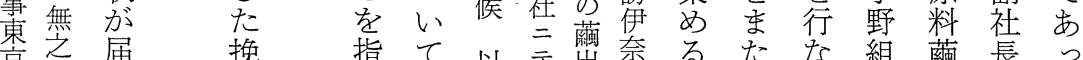

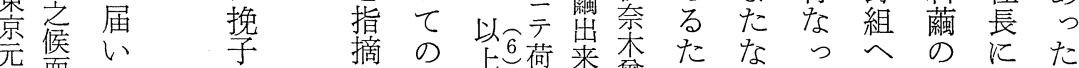

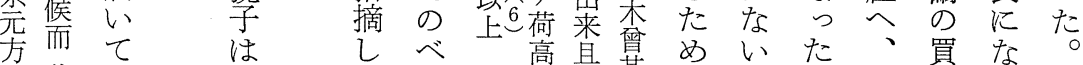
公い最たて 改疵其ののこ細付る

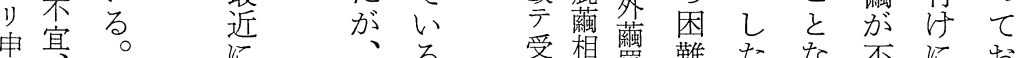
来、にる受想綇難たな不に特 》兼九月

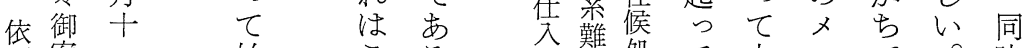

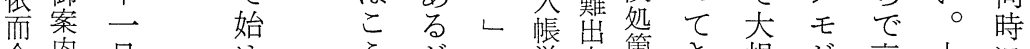

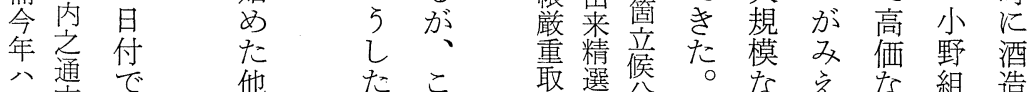
八通で他 たこ敢選分侯同な えなな 組造

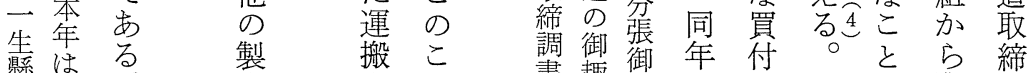

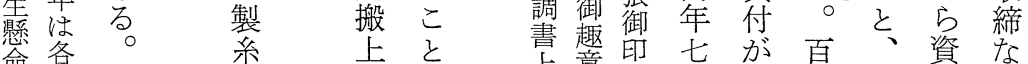
命各系上 上 青億印七㔯百、資な 各所業の喓紙月行人ま金ど 所器者 当 可、無七な挽た を无

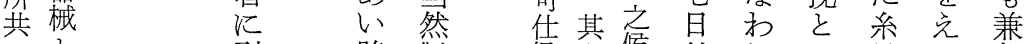
二 引引路製候上候付れい目て 任

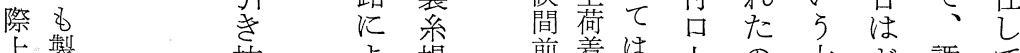

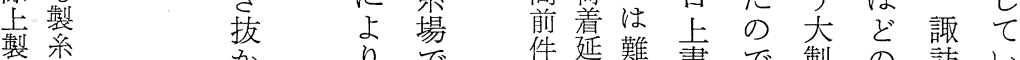

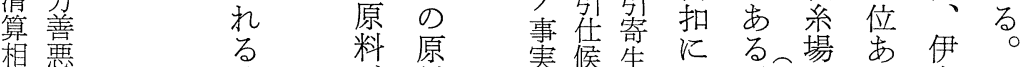

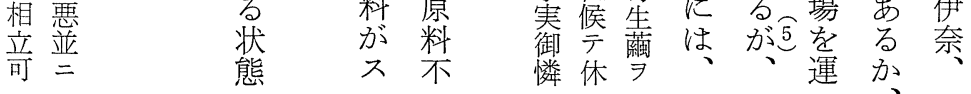


第 2 巻第 3 号

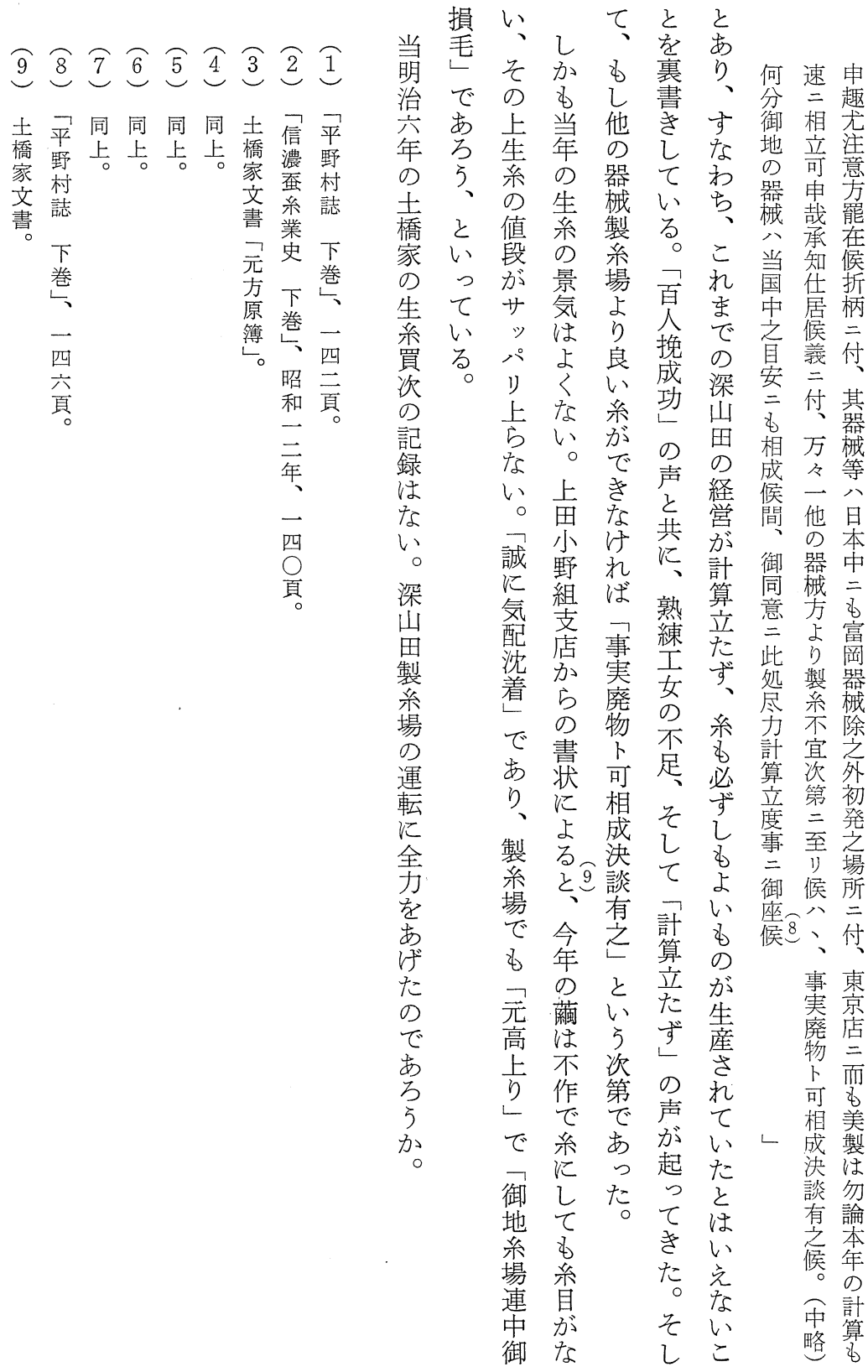


経営史 学

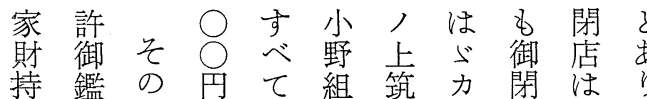

悉を同小却 5 方処被然一五立夜書㗠方士

皆壳同小野乙負江御成の一泚最登音年手橋

売売七野てっ御不候こ 0 蒲閉足筑以百七家

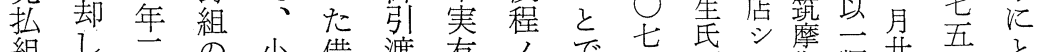

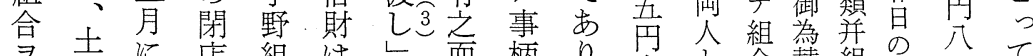

以 橋

借家醬で学六乙 御

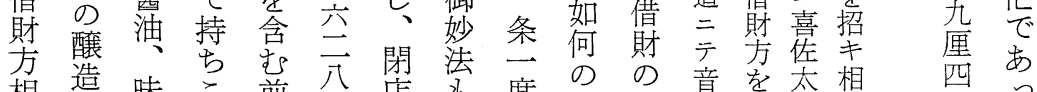

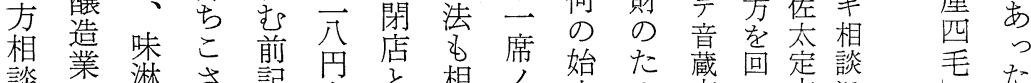

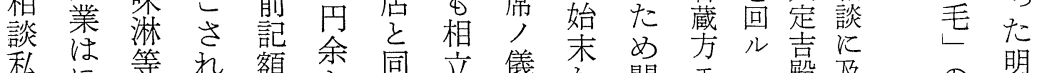

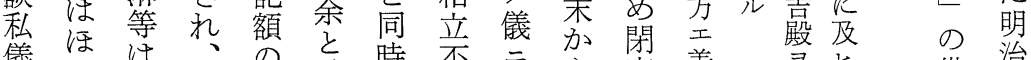

者者

妻ぞ身 店 財 算 深 ᄂ 有 に

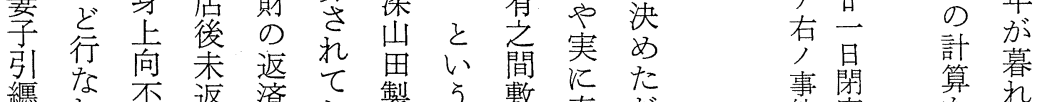

纆わ不返済执製ら敷奉た 如件店をを

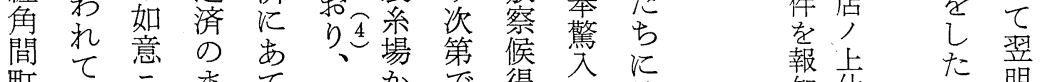

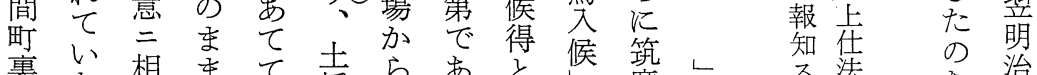

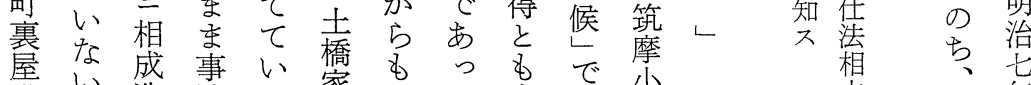

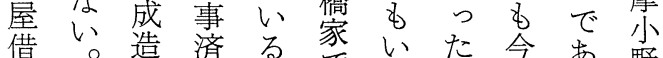

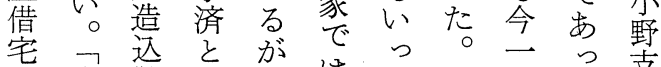

江身難な 方は段で支

営上出つ完こい橋御こ店

方向来7て 済れ手家節二向連

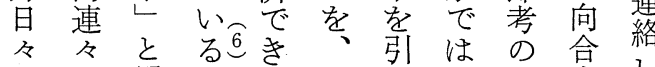

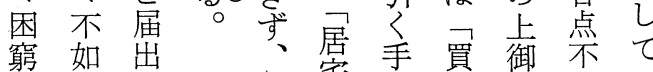

罷意を結宅段次仕参い

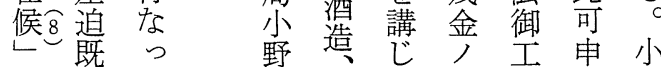

で当て組持て 外風失野

あ二特 の萔い器可索組

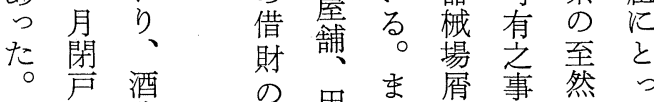

仕造年思市事然つ

居の ら地主不然被士

宅 御 家橋残奉 存 橋

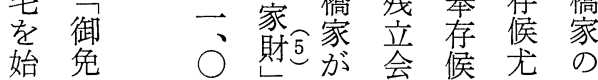


第 2 表 明治 5 年以来総入用表 (1)

\begin{tabular}{|c|c|c|c|}
\hline 入 & 金 & 支 & 払 \\
\hline 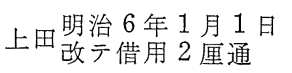 & 2,600円 & 5 年挽入用金利トモ & 1,303円54銭 \\
\hline 上田明治 6 年 5 月 6 日 & 7,000円 & 6 年铜代金 & 4,952円 41 銭 \\
\hline 土橋家 & 1,184円 24 銭 & 挽立入用飯費炭薪日給共 & 2,181 円 70 銭 \\
\hline 屏物代 & 253 円 83 銭 & 7,000 円利子 & 351円75銭 \\
\hline サナコ井代 & 26 円54銭 & 改料駄賃荷造 & 37 円98銭 \\
\hline $\begin{array}{l}\text { 利子附カリ } \\
(2,600 \text { 円 })\end{array}$ & 312 円 & 系小以 & 8,827 円38銭 \\
\hline "'(7,000円) & 351 円75銭 & 5 年器械入用 & 1,315円19銭 \\
\hline 土橋家 & 300円 & 6 年 $\quad 11$ & 1,400円62銭 \\
\hline 見本系荷組入共代 & 37 円23銭 & 両年分利子 & 410 円 82 銭 \\
\hline & & 器械小以 & 3,126 円 63 銭 \\
\hline & & 小物貸 (上田・松本 · 中条) & 48 円 36 銭 \\
\hline & & 5 年伊奈镉口銭 & 55 円 65 銭 \\
\hline 総 計 & 12,065 円 59 銭 & & 12,058円2銭 \\
\hline 引 & & & 7 円 57 銭 \\
\hline
\end{tabular}

第 2 表 明治 5 年以来総入用表 (2) 内訳

\begin{tabular}{|c|c|c|c|}
\hline \multicolumn{2}{|c|}{ 婏賃ならびに糸売却代金 } & \multicolumn{2}{|c|}{ 資金ならびにその利子 } \\
\hline 5 年春瞄賃挽 & 242 円 88 銭 & 上田 1 月 1 日改入 & 2,600円 \\
\hline " 夏蒇挽 & 1,288円6 銭 & "I 利子 & 312円 \\
\hline 岩村田䋠賃挽 & 559 円 62 銭 & 上田 5 月 11 日, 6 月 25 日 & 7,000円 \\
\hline 上田小物貸扣よび見本系代 & 49 円57銭 & "I 利子 & 351円75銭 \\
\hline 松本賃挽 & 196円96銭 & 土橋家 & 1, 484円24銭 \\
\hline 松本小物貸 & 16 円2銭 & & \\
\hline 新系15個 2 分売込代 & & & \\
\hline 残り屑物 & 122 円33銭 & & \\
\hline & & & 11,747円99銭 \\
\hline
\end{tabular}


経 営 史 学

あ営設大什も組すす営る 明製すすり

と土でさ曲器なはるそ責様治系る

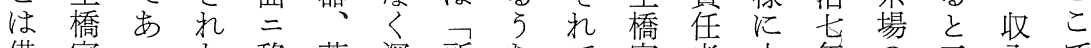

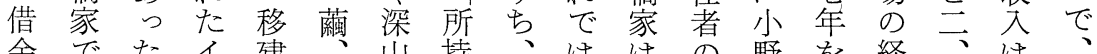
金では た

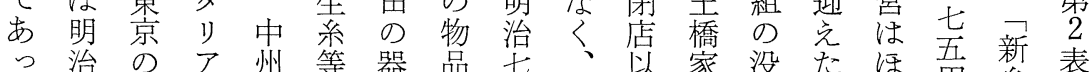

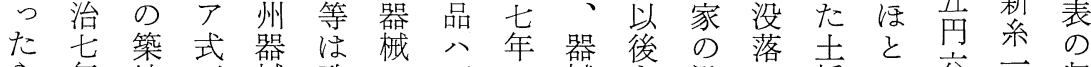

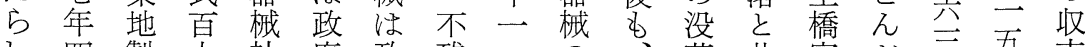
乙四製人社府政 残一の、落 共家ど 銭五支

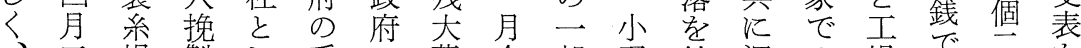
三六場製し 手 の 蔵今亲部野結深

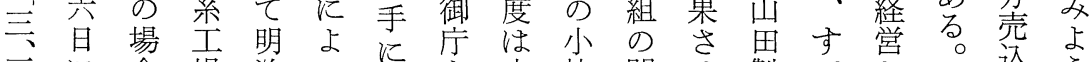
三六醬よ合場治っ っ

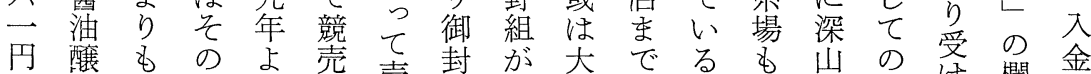

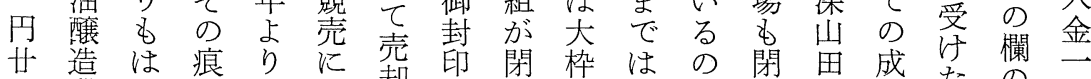

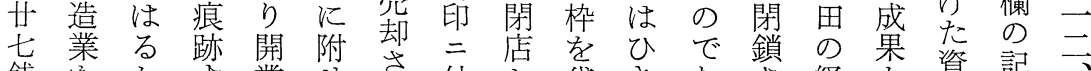

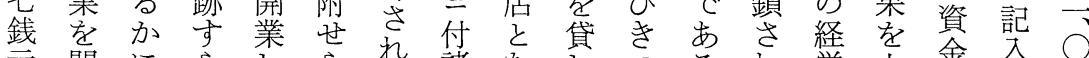

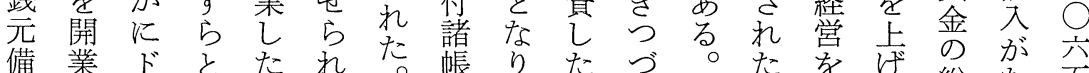

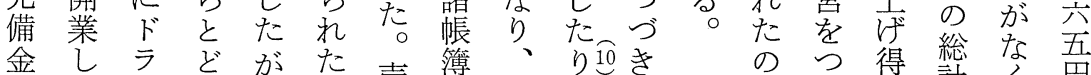
金して ス め

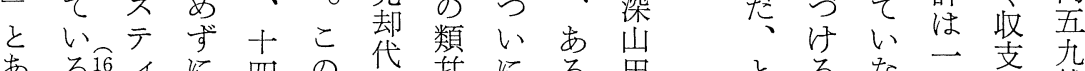

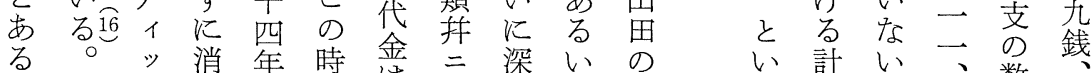
る 资 消 年 時金三深いの

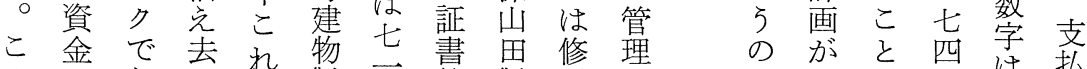

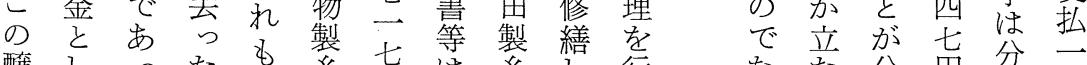

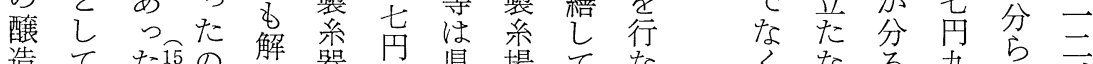
造てた可の解 器円県場て な 業、。で散械云庁は小先

は一頪 あて 銭へ完規て

の類学て切鈛占全模い

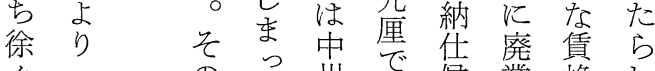

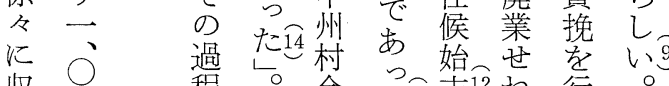

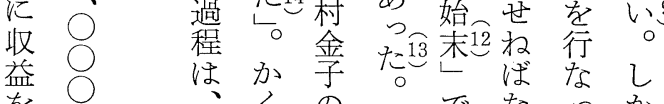

を円くの結でなっか

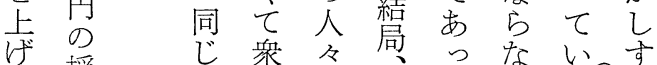

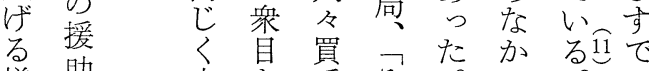

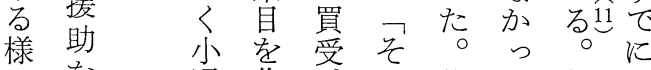

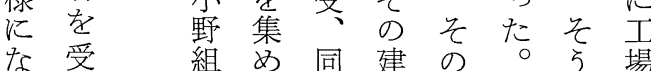

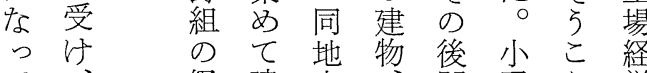

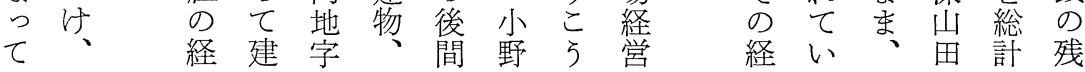


第 2 巻第 3 号

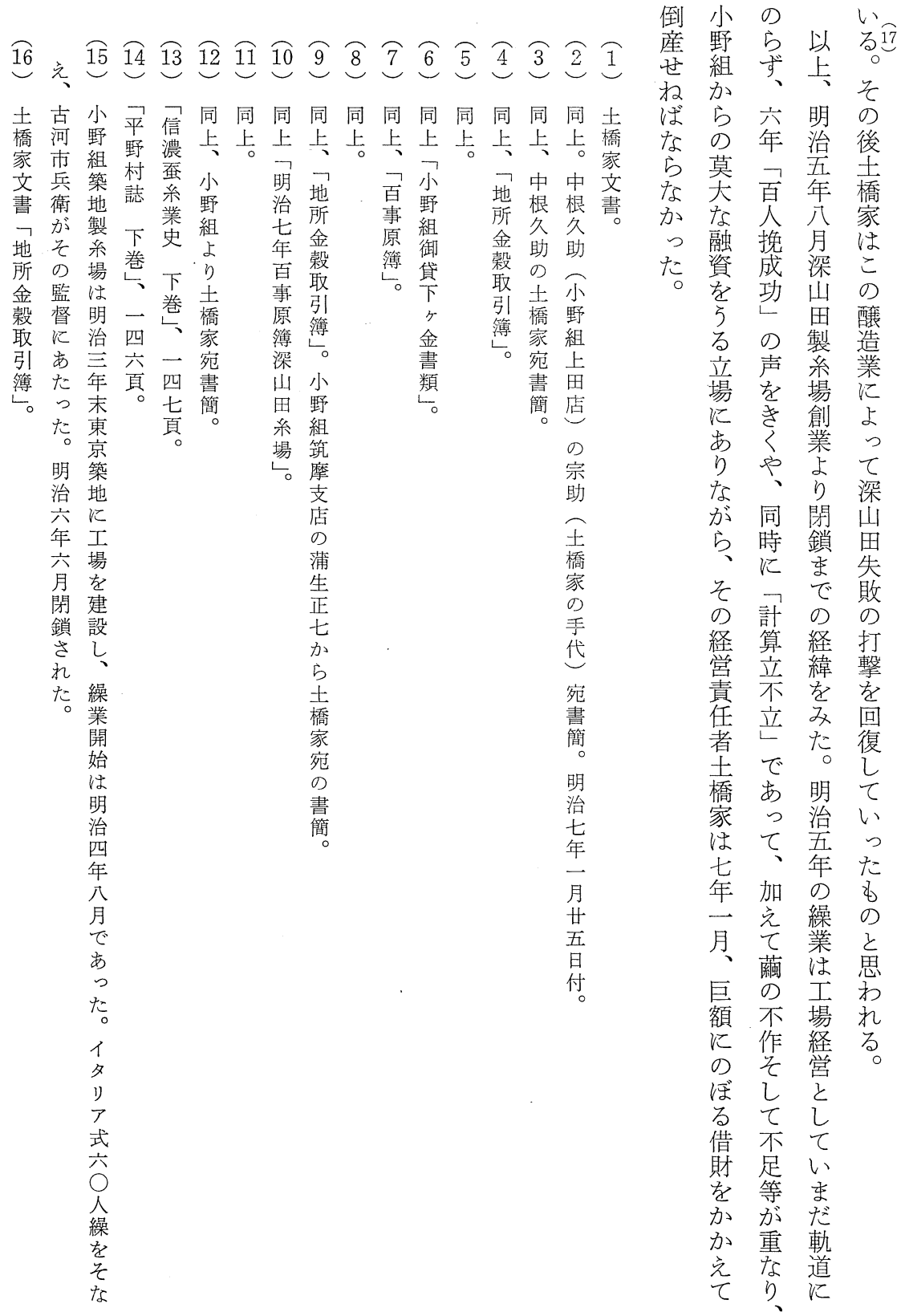


経営史学

分二を洋あむ富

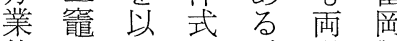

的に通す器架様製ず、熟

りじ○製深の場々 練

き而煮糸山移はのを

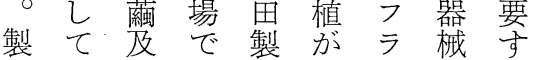

系煙繰 あ糸行ンのる

のを杀っ場なス検器

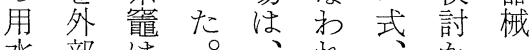

水部任父、机、加

は煙全乞明、小ら

人筒部こ治種野入

力に連で三々組つ

に発䁍ま年改築て

て散装ずよ修地い

運せ置築りさ製こ

搬しなる 地建製設糸

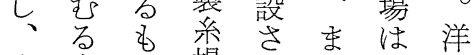

小方、場れたイ式

样法火のたは夕製

にに炉設小爯り系

汲ては備野様ア器

取、都を組式式械

り者藏 又築㤎で移

て 葤—る地折 あ 植

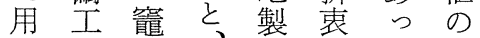

い女を系さた試

一繰 製場 れと文

者名糸糸学ていは、

䓝之一器模 明 5

及繰酉械倣治こイ

び系とはし々 々

繰工を劣たけはリ

糸女連製个年一ア

湯云絡衣

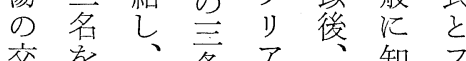

交を孝条了知

換一煮繰 式徐 5 ラ

は組瓮直器々れン

柄との繰磷にてス

杓な下製定い式

をしに角焚し采着る。昜

い煮乞て㗎て信様

た蘭火運信い州で

り法力転州っに行

○はを㵊た抏な

生殆繰人初のいわ

系䒺力のでてれ
少かりリ

いっにア 輸

史たも式出

料加空深貿

を。出山易

検 前か田 の

討記っ製 花

乙中采形、深

な 根 現 場

㤎久実の生山

ら助孝余系田

、のおりの製

書れに增糸

夕面わ放場

リにれ急崩

ア み激殖壊

式 5 今な 産の

製れ少崩興原

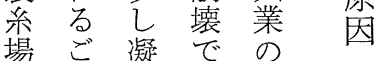

のと視あ華

生々 ᄂ っ

産、なた

場橋㕲成吕

に家浪盛将

近経 5 婏

乙営な 立

$\tau$ の

みや。理に

る り な

そりか粗ぎ

ににか製に

しマる のき

占御急污

実な学大

有崩脱が

之壊ジか

で途とな

あ学の建

った 土 設

たど橋を

たら家行

め敞のな

なば壮っ

のな図た

から $\overparen{17}$

四 上

山

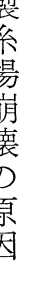


第 2 巻第 3 骂

にてつの

よ抱将抱

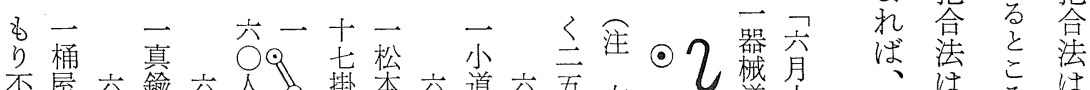

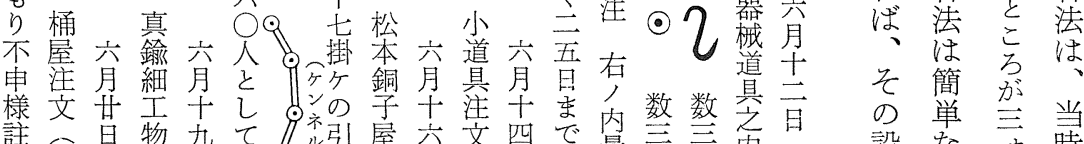

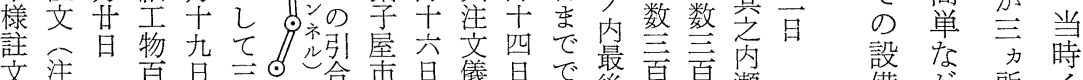

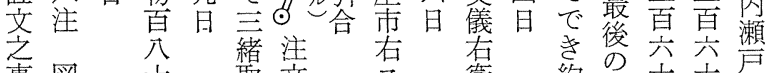

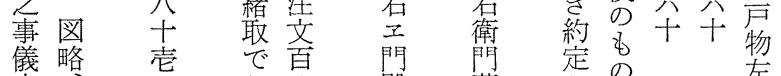

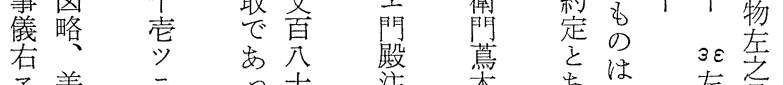

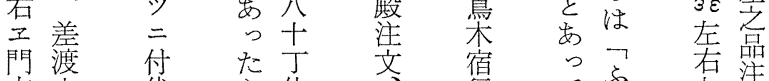

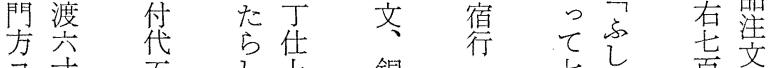

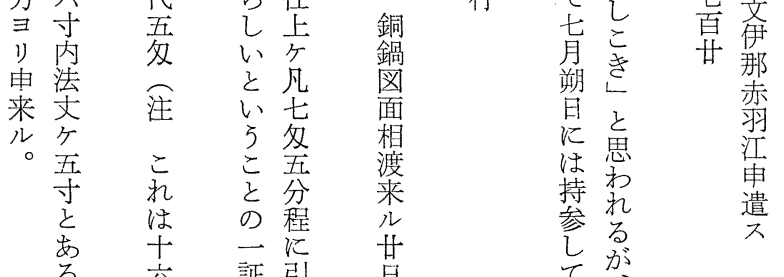

備 が 所イ

のら市ナ

様イをる゙ 子夕泉名 次少南称 の風繰 し ごの繰 こ そ ケ でネり、亦 あ ル式動に 注あでの ま令古最 合 証引 合 迄

外注 る。注

蛹 の

渡只旮差

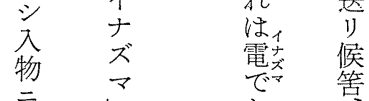

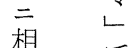

想で

候市

$\begin{array}{ll}\text { 㽞 } & \text { 弓 } \\ \text { 是 }\end{array}$

て

る。赤

る、然

のこ繰長

は和系さ

平を梳六

野 深 釜 七

村山釜 寸

誌田 三

巻場 組 㯰

の とで り豆

引比 あ ᄂ

用較り、と

さ注

之交

方快

乙 小

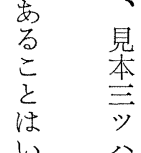

浽

所て 煮り

附, 又繰、

位 島

二 郎

而安

罊离

候

无

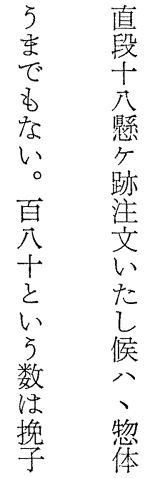

率

る小照 引

छ野市

器 め 取

。械た

方合系 
経営 史 学

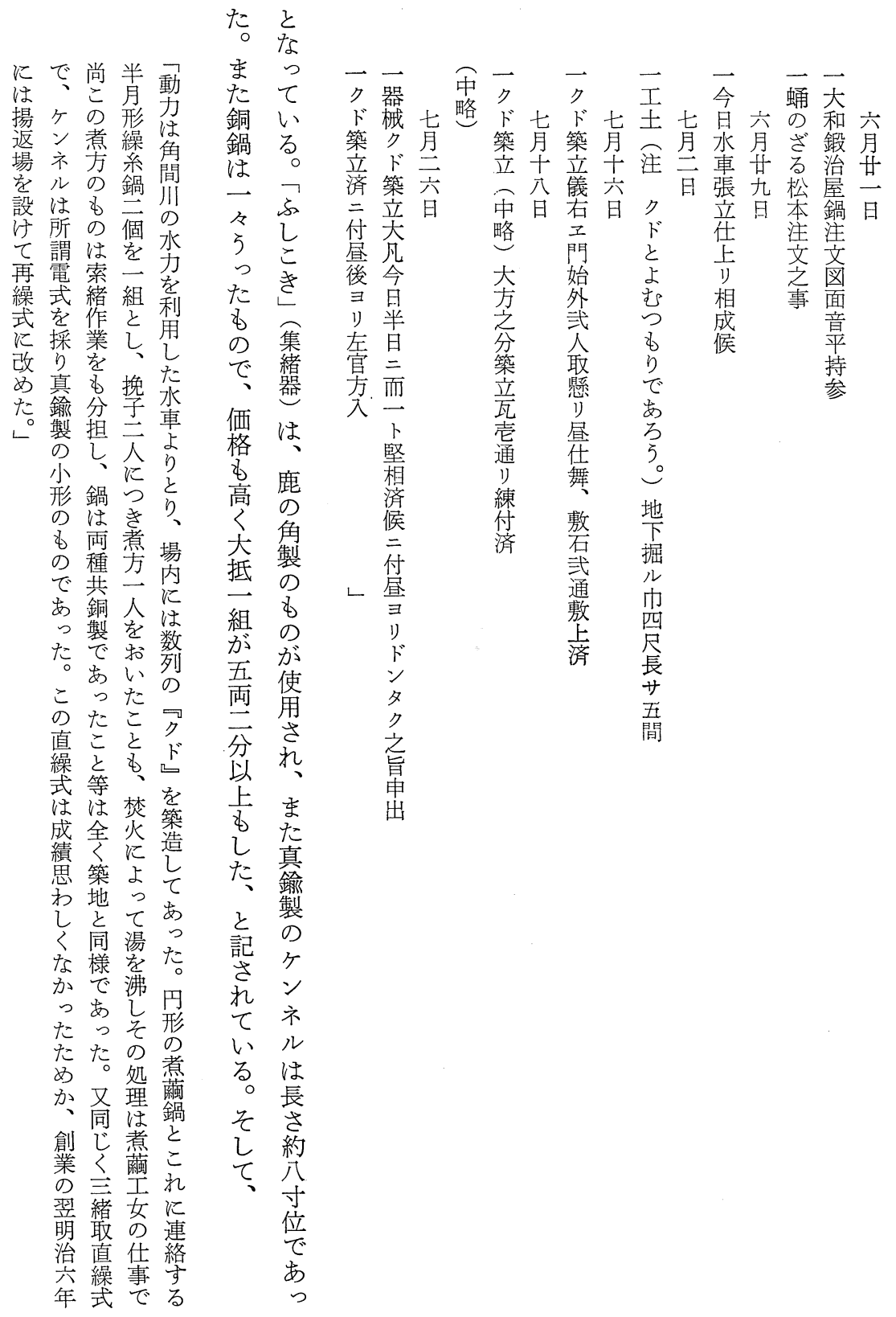


第 2 巻第 3 号

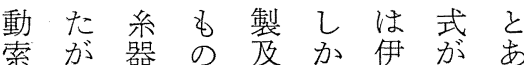

緒っ械な鉄乙国徐り、個製ン届

は、概にあ伊来に当上業!圣

有築䃿非り仏の姿時りにル萦

乙地鉄ずとに製索イ更蒸氏業

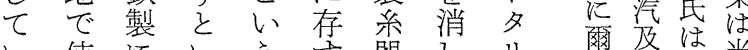

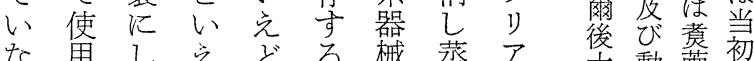

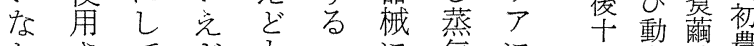

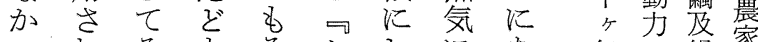

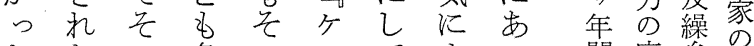

たたの多のンてよっ間㥕系副

様型く大六二るて用に副

等式走はき名動は拄蒸的

々 はび手さ伊召、心浢事

○イ構に形式国、人製張㽞業

乙夕造依状製式繰力製张势棌

かリにり等系と系を業れ製属

もア各索は器称の動㥒器

、で種緒我械し操力大公法战

伊当学国中、作々 い学少

国旧る行に思伊をし六発運

国式しな普の、行煮登年見遇

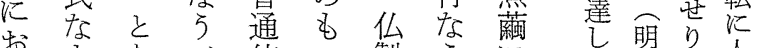

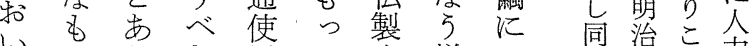

てのりき角と糸様は時旮机力

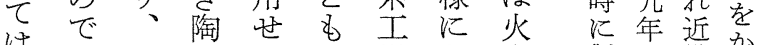

はあ オ器ら旧場な力

そっタ製る式にっ を

のたり摺るな和て用

規こ ア 鉢をる る

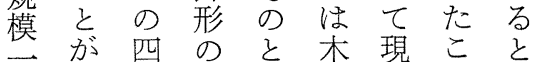

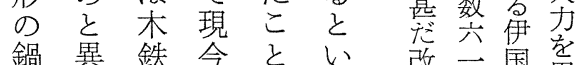

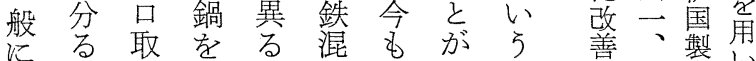

大。角所製口分、竞公䒺た

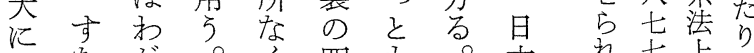

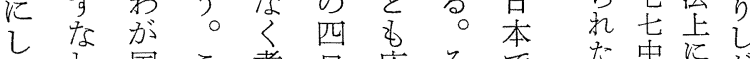

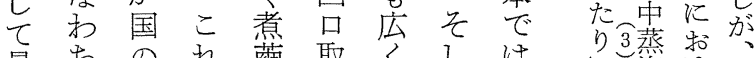

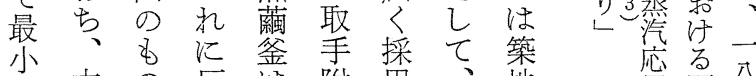

二木の反附用、地

○鉄と混二自に動し せ

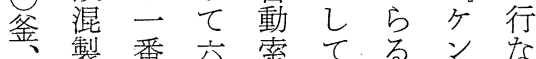

最で似口緒繰る亦方

大煮て 取篣系器ルれ

二铜和以を釜械见て

釜り上具渷な式い

は、市ら陶り器た

釜自乙製る哭。械様

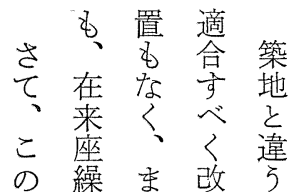

築器た修と

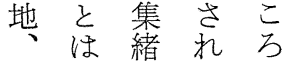

深 決器ては

山定も い動

田的なる 力

のにく。方

器相手し人

械違先少力

をしでしか

更た行改ら

江西な修水

本のっさ車

場でてれに

のあいたな

イったとっ

タたもはて

リこのいい

アととっる

にが比てこ

物分較多亡

汗る括在

る。れ来六

も福のし

の、製て

と六系直

比 $\bigcirc$ 器 繰

較人の

乙 繰 座 再

よ 繰 繰

百㤎湾

人手な

繰取呵

之 器 て

いでい

ろケる

器 ソ 等

用顕

の著五

釜方年

数良交

は良交

五引华

六主年

豆爾サ
のルよ

規のり

模 ご 日

学々本

別きの

之抱 事

乙 合 情 
の百で○止でれい熟こで尾で二と十内

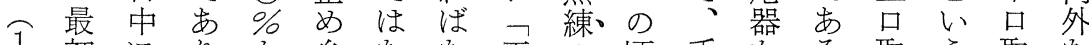
初にりを系なな工市頃手をる 取ら取な

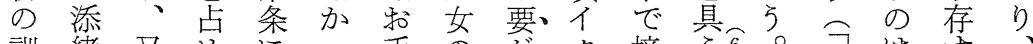

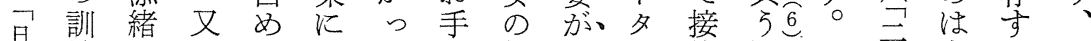

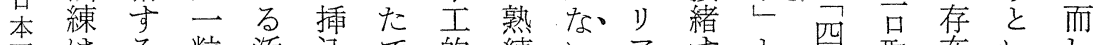
亘はる 粒添込で的練いるアすすと取在いし

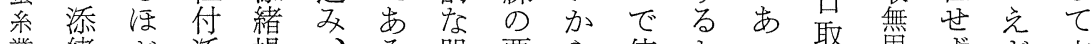

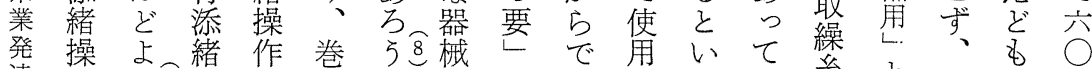

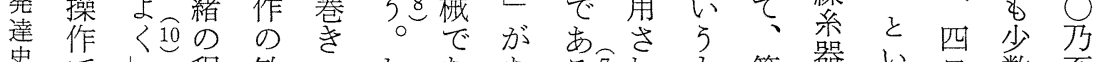

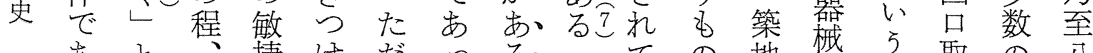

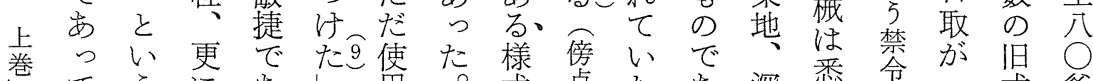

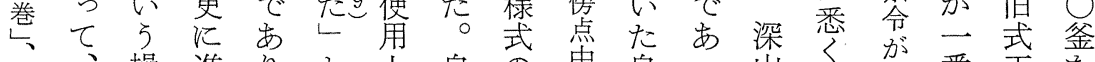

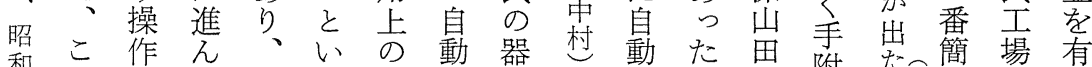
和のので且 $ら$ 操式械。接がに附奆簡場有 六訓段添つご作のです緒ら据に省なな除る

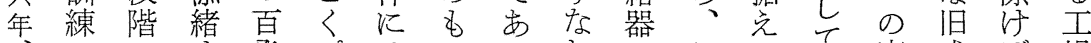
、のに守発プはのうわ注こうて座武ば場

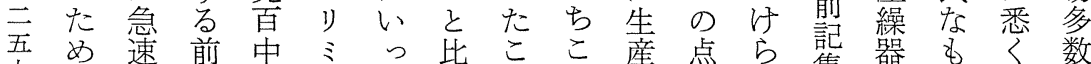

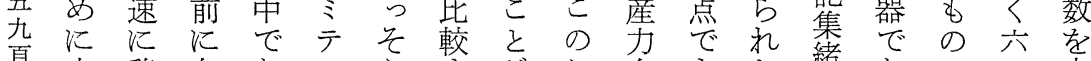

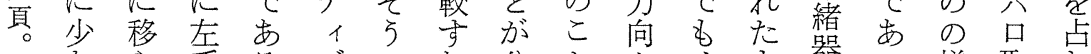

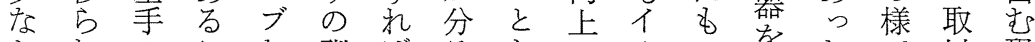

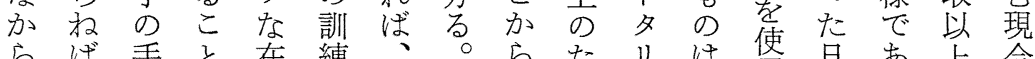

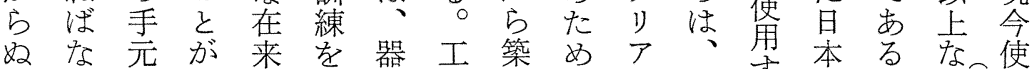

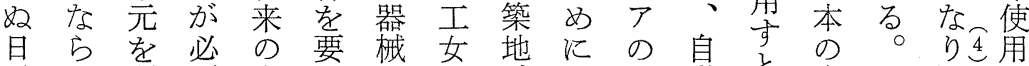
子な顧要方し向の、是旧動と事こしせ をい又孛法た施訓深韭式式い情れでら 要困てこ加設練山必なでえがをある す難一のらす作に田要するば考受っる

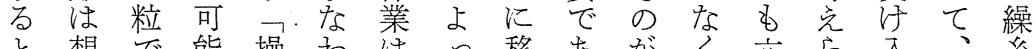
と想で能操わ注り移あ がく六ら入入系 い像あ的作ち容て 植ると、和築釜

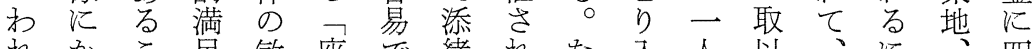
れかこ足敏座で緹れな入人以、に四

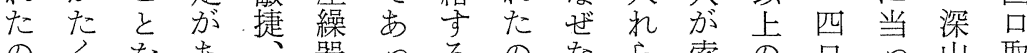

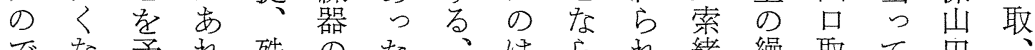

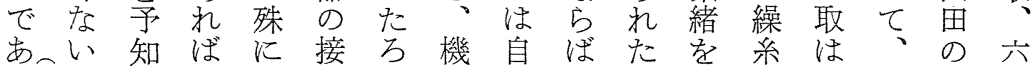
る11。乞 あ 繰尾 5 械動添こし㗊無多如口

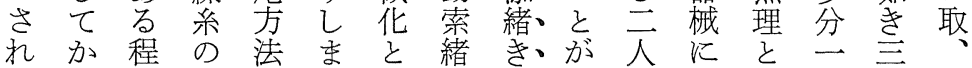
ばら成全はたいのわ分がは考口緒八

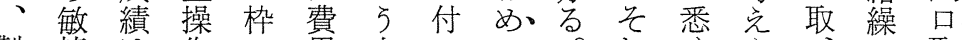
製捷 系によの回む加て容さをを自机ま主及 工百い紜多ら軽らら受動たた只稀

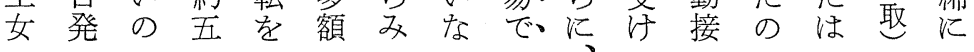


第 2 巻第 3 号

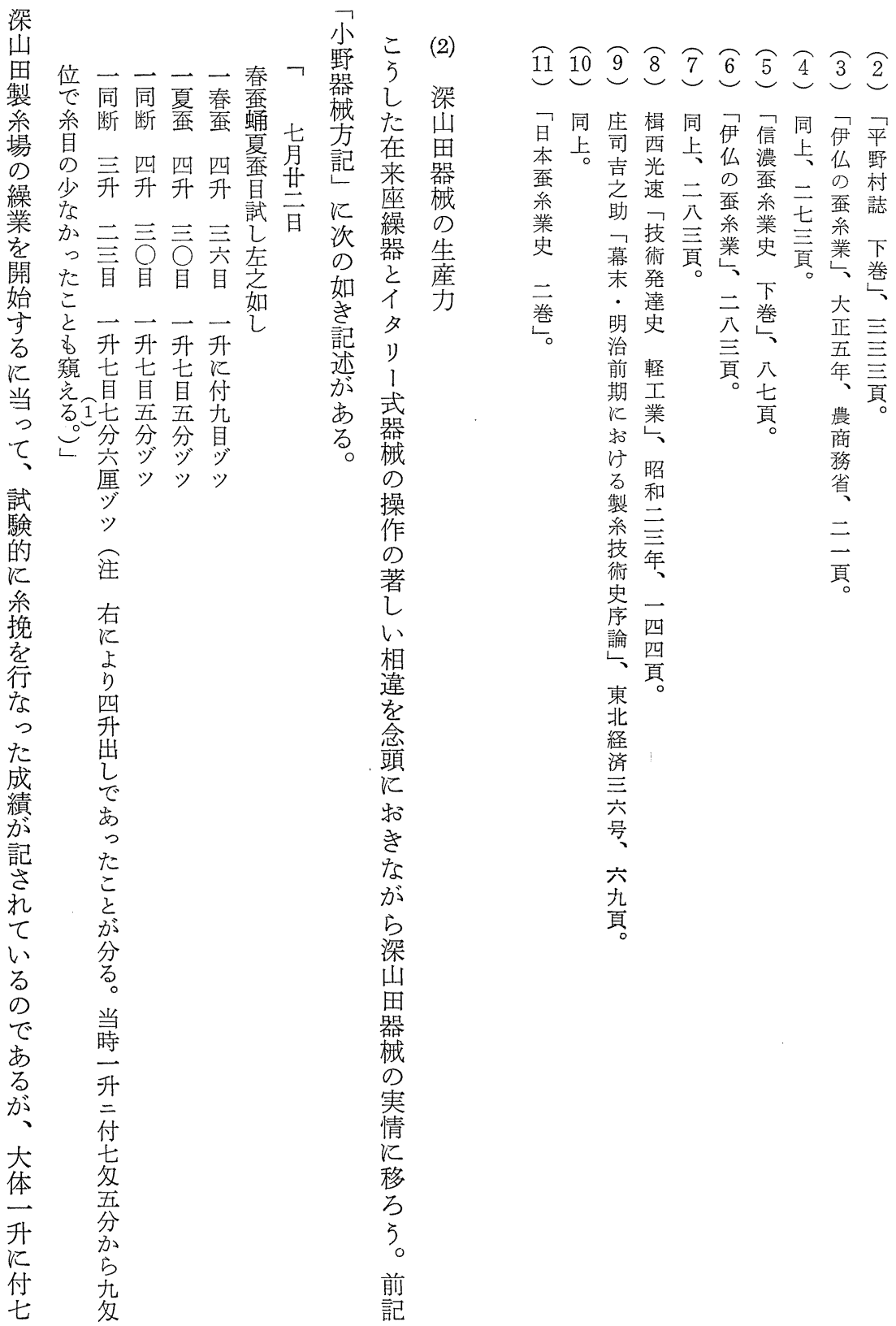


経営史学

第 3 表 明治 7 年

\begin{tabular}{|c|c|c|c|c|c|c|c|c|c|}
\hline 工 場 名 & 工女員 & $\begin{array}{l}\text { 就業日 } \\
\text { 数 }\end{array}$ & $\begin{array}{l}\text { 年製糸 } \\
\text { 高 }\end{array}$ & $\begin{array}{l}\text { 元荋菌 } 1 \\
\text { 円 } \\
\text { 取 }\end{array}$ & $\begin{array}{l}1 \text { 升糸 } \\
\text { 目 }\end{array}$ & $\begin{array}{l}1 \text { 日 } 1 \\
\text { 人繰目 }\end{array}$ & $\begin{array}{l}\text { 百斤入 } \\
\text { 費 }\end{array}$ & $\begin{array}{l}\text { 百斤売 } \\
\text { 価 }\end{array}$ & $\begin{array}{l}\text { 損 } \\
\text { 益 } \\
\end{array}$ \\
\hline 富岡製糸場 & 450 人 & 288 日 & 13,593 斤 & $\begin{array}{c}\text { 多 堙 } \\
21.42\end{array}$ & $\begin{array}{l}\text { 多 厘 } \\
6.40\end{array}$ & $\begin{array}{rr}\text { 多厲 } \\
16.78\end{array}$ & $\begin{array}{r}\text { 开 } \\
450\end{array}$ & $\begin{array}{r}\text { 周 } \\
782\end{array}$ & $\begin{array}{r}\text { P } \\
55,268\end{array}$ \\
\hline $\begin{array}{c}\text { 外上等 } \\
\text { 器械製糸場 }\end{array}$ & "I & $\prime \prime$ & 21,060 & 36.00 & 7.38 & 26.00 & 208 & 710 & - 12,214 \\
\hline $\begin{array}{l}\text { 外中等 } \\
\prime \prime\end{array}$ & $\prime \prime$ & "I & 16,200 & 38.00 & 7.10 & 20.00 & 175 & 650 & 8,748 \\
\hline $\begin{array}{l}\text { 外下等 } \\
\prime \prime\end{array}$ & "I & 'l & 12,150 & 38.00 & 7.00 & 15.00 & 175 & 600 & 468 \\
\hline 上 等 座 繰 & "I & "I & 19,440 & 38.00 & 7.50 & 24.00 & 130 & 600 & 9,525 \\
\hline 中 等 座 繰 & $\prime \prime$ & "I & 17,010 & 41.00 & 7.30 & 21.00 & 720 & 480 & 3,016 \\
\hline 下 等 座 繰 & $\prime \prime$ & 11 & 13,770 & 42.00 & 7.00 & 17.00 & 600 & 410 & 2,754 \\
\hline
\end{tabular}

（注） 群馬県蛋采業史.

第 4 表 明治 5 年 8 月以来明治 6 年 7 月 系挽立表

\begin{tabular}{|c|c|c|c|c|c|c|c|}
\hline & 松 本 & 桠 & 他 & 岩 & 村 & 菻藏 & 合 計 \\
\hline 立石数 & 39石 7 斗 7 合 & $\begin{array}{c}\text { 冬 换 } \\
23 \text { 石 } 3 \text { 斗7升 }\end{array}$ & $\begin{array}{c}\text { 春 挽 } \\
19 \text { 石 } 4 \text { 斗 } 4 \text { 升 }\end{array}$ & $\begin{array}{l}\text { 19石 } 1 \text { 斗 } 9 \text { 种 } \\
\text { 6合 }\end{array}$ & 40 石 1 斗 5 升 & 30 石 2 斗 2 升 & $\begin{array}{l}167 \text { 石 } 2 \\
\text { 斗 } 9 \text { 升 }\end{array}$ \\
\hline 生 系 & 23貫863多 & 15貫115多 & 16貫156多 & 14貫976多 & 32貫 435 多 & 22 貫 790 多 & $\begin{array}{l}124 \text { 貫 } 935 \\
\text { 为 }\end{array}$ \\
\hline 1 升平均 & 6,562 & 6,468 & 8,336 & 7,593 & 8,079 & 7,215 & 7,468 \\
\hline $\begin{array}{l}1 \text { 日 } 1 \text { 人 } \\
\text { 平均 }\end{array}$ & 5 升 6 合 6 勺 & D 5 升1合1方 & 3 升4合5勺 & $\begin{array}{l}2 \text { 升 } 8 \text { 合 } 9 \text { 勺 } \\
\text { 新子多乙 }\end{array}$ & 3 升1合3 & 2 升7合 7 勺 & 3 升 5 合 6 \\
\hline 婏立人数 & 642 人 & 432 人 & 562 人 & 664 人 & 1,283 人 & 1,084 人 & 4,667 人 \\
\hline 稼動日数 & $\begin{array}{c}\text { 明治 } 5 \text { 年 } \\
8 \text { 月 } 8 \text { 日 } \\
\text { 10月21日 } \\
52 \text { 日間 }\end{array}$ & $\begin{array}{c}\prime \prime \\
10 \text { 月22日一 } \\
\text { 11月19日 } \\
25 \text { 日間 }\end{array}$ & $\begin{array}{c}\text { 明治 } 6 \text { 年 } \\
4 \text { 月 } 6 \text { 日〜 } \\
27 \text { 日 } \\
18 \text { 日間 }\end{array}$ & $\begin{array}{c}\text { " } \\
4 \text { 月 } 28 \text { 日 } \\
5 \text { 月 } 12 \text { 日 } \\
13 \text { 日間 }\end{array}$ & $\begin{array}{c}\prime \prime \\
5 \text { 月13日一 } \\
6 \text { 月 } 8 \text { 日 } \\
27 \text { 日間 }\end{array}$ & $\begin{array}{c}\quad 11 \\
6 \text { 月 } 9 \text { 日一 } \\
7 \text { 月 } 5 \text { 日 } \\
34 \text { 日間 }\end{array}$ & 159 日 \\
\hline $\begin{array}{l}\text { シケ糸, } \\
\text { キヒソそ } \\
\text { の他 }\end{array}$ & 7 貫656多 & & 4 貫819多 & 7 貫735多 & 15貫236多 & 10 貫 790 斥 & $\begin{array}{l}\text { 48貫 } 176 \\
\text { 多 }\end{array}$ \\
\hline
\end{tabular}

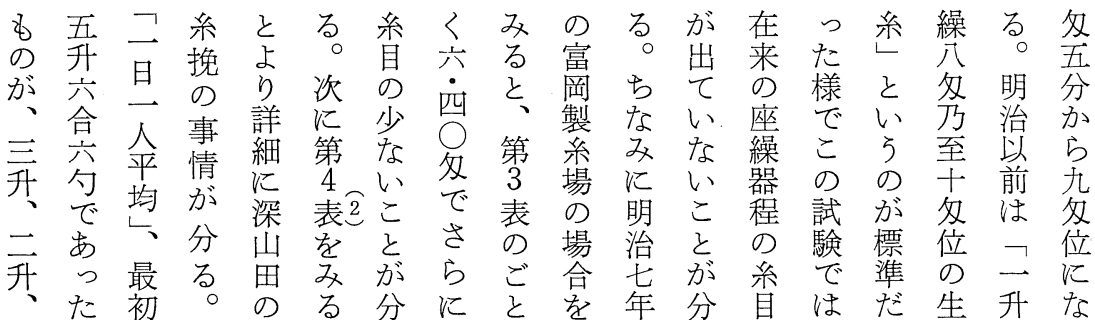


第 2 巻第 3 号

付ででと

のあなな

半る以っ

分袽、て

の深日心

能山本る

率田に。

むの移労

出製植働

て系さ 時

い状机間

な態たは

いを名、

○第の日

そ 4 に本

の表近の

生江場

産よっ合

力ったは

のてと文

大 二小体

ま人 5 こ

相 日 之 時

違繰は 間

が系前で

分の記あ

る平しっ

の均たた可

あ゙学深

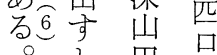

之田 取
六

立辛付

分取之

术い

な

り出将

个対 接

夕 等 緒

リ の \&

ア比自

の較 動

四式

口不の

取可名

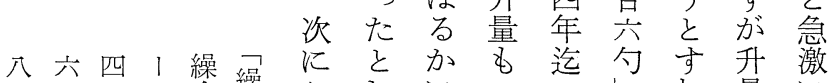

口口口儿糸繰こしにコてしれ量に

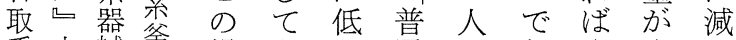

六四手内械金繰毛少通二市系少り

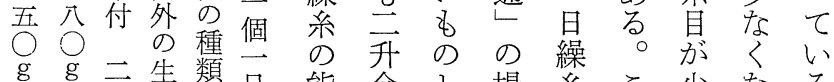

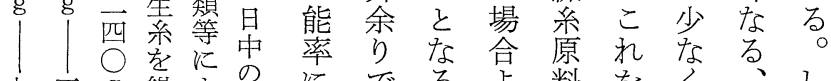
七五 $\mathrm{g}$ 繰 よ繰 $\bigcirc \bigcirc$ 場大皇い深富も栘来るいし $\mathrm{g} g$ 合差量て山岡低最のと只 二二三に市原本田のい多升い関二

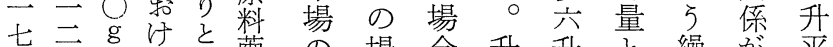

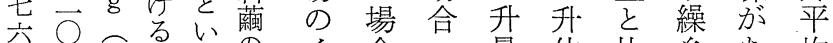
公多五党のイ合皇位比系市均

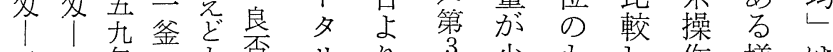
リり 3 表少文作様は、 艻繰ヶ

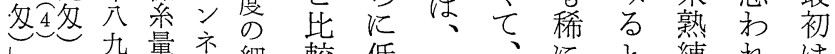

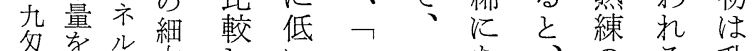

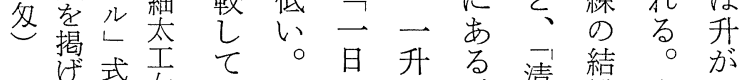

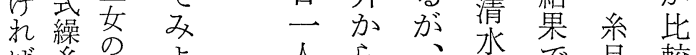

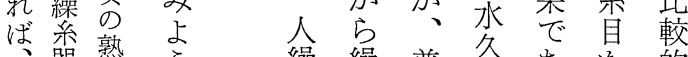
概械練 5 繰繰普左あをを的 ね机な糸通左引 多多

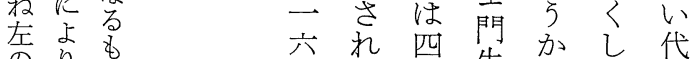

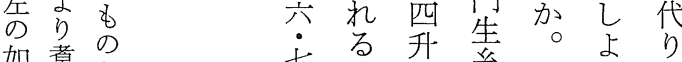

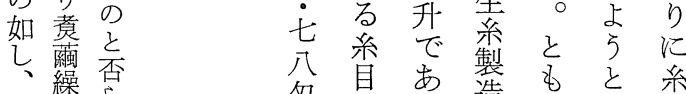
但糸䒺 百劣る の業す

作々 時伊に 間内よ は地り 十産又 一繶 時を操 間以作 子分 。土業 デ如 二及

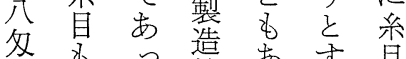
でもつ簿 あす目 あ样溥机杪 あ低芯い升升な 万乐全少後 升々とる 部なに 量の市々平々は b生 り、均、它 二産、明专升の

升量深治る量糸

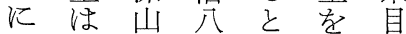
付標田年 八準のよ三人量 多場り升し屋 あり合十五よ增 てか方芆て 量 量い 
経 営 史 学

美り

麗と

の

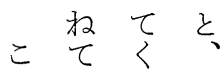

ない治練のつ机計

るっ八工様製と算

とて年女糸い䒺

に製、の深方い立

由糸米不山忹子

技国足思入䒺様

そ術加念自に

ののら繰繰系出再

後重の糸系貝方兰

の要報にに出し注

もな告沶拉方澺

そ こ に

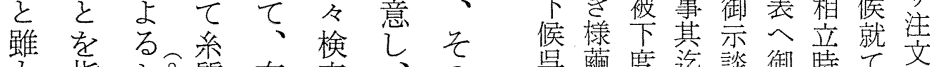

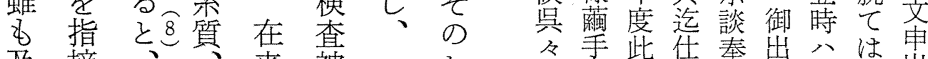

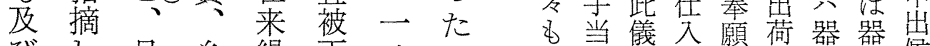

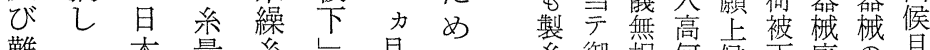

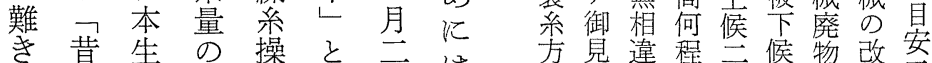

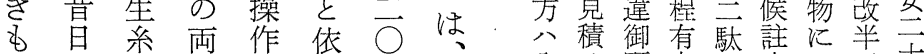

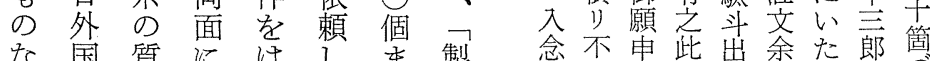

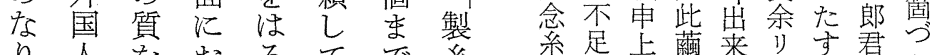

り人を括るてで䒺

上の向いかいは工

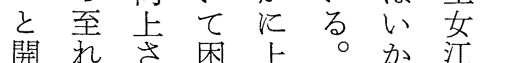

慁蛹候製次候第等出出

開至上卡 て

港る せ難回

以以る肪る

前前にあ 熟

ののはっ練

わ綟った度

が系精こを

生は巧之要

系年 耐 方

のの忍分る

質紡 な る

の系学優の

良法方学 式

で法劣言

全

た成に適使

と学角

な注々向

〈意検可

乙御查申

䭾被臂春

位下章年

拄廉

生 製

産 系

万来

様不

式时

乙 様

箇荷成悉泟漛

付願上御意入

程踟尚配着候

章前

值慗尽被し

$\frac{⿱ ⺌}{3} \underset{5}{5}$

己

以当

事 -

態 其

を器

背 械

景 抔

には

小旦

野 本

組 中

加 に

58

橋 岡

家 器

に 械

次 除

の 之

様 外

な 初

書 発篦

が そ

か い

かわ

れ れ

たた

之深 立り少安被廉越市田 の新但 へ上系算年製

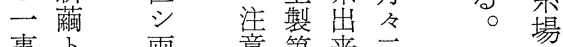
事卜両意第来云时 御程何被京御申筒付能

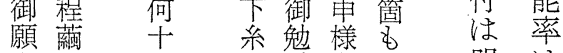
上石厘目励御出

电数二出奉入来

欲呉候入妏学願念候

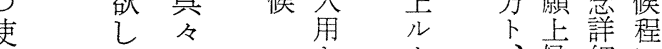

を学县它

の る る

ベ総に

认为

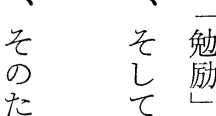

之

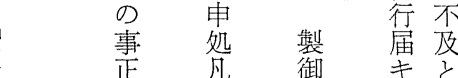

て

、候細湾

明は

治 非

六 常

年に

九低 
第 5 表 明治 6 年深山田製系場 100 斤あたり生産費

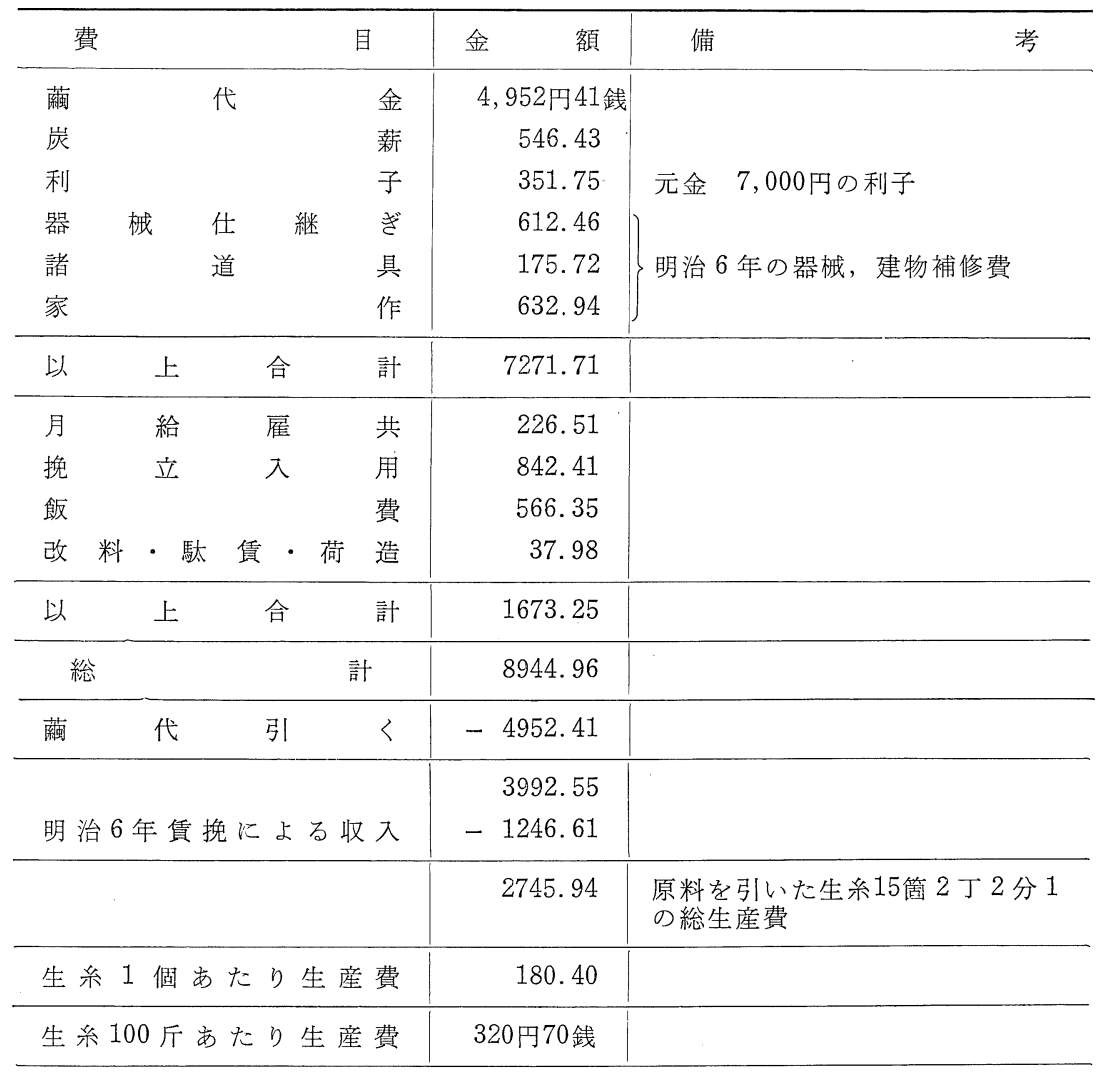

はし日本深こ器きてに粗希り格るるると

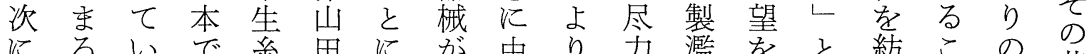
にるいで糸田に染由り監ををと紡この 昔

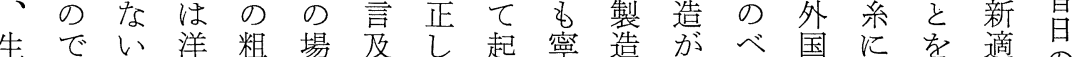

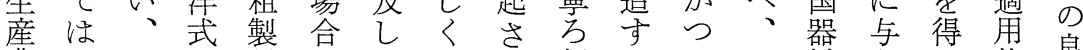

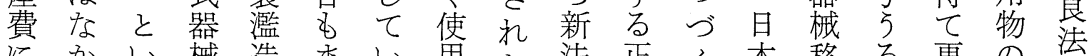
にかい械造ま秀角た法正く本移る 更の

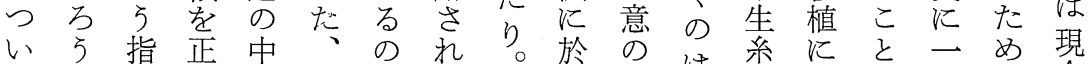

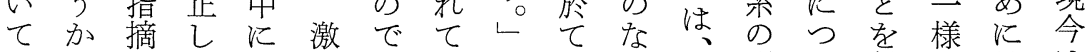
又。がくあしあいと経きを烈い得及及補は

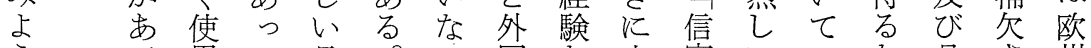
5 て用て 日。い国な由実いのな品さ州 
経営史学

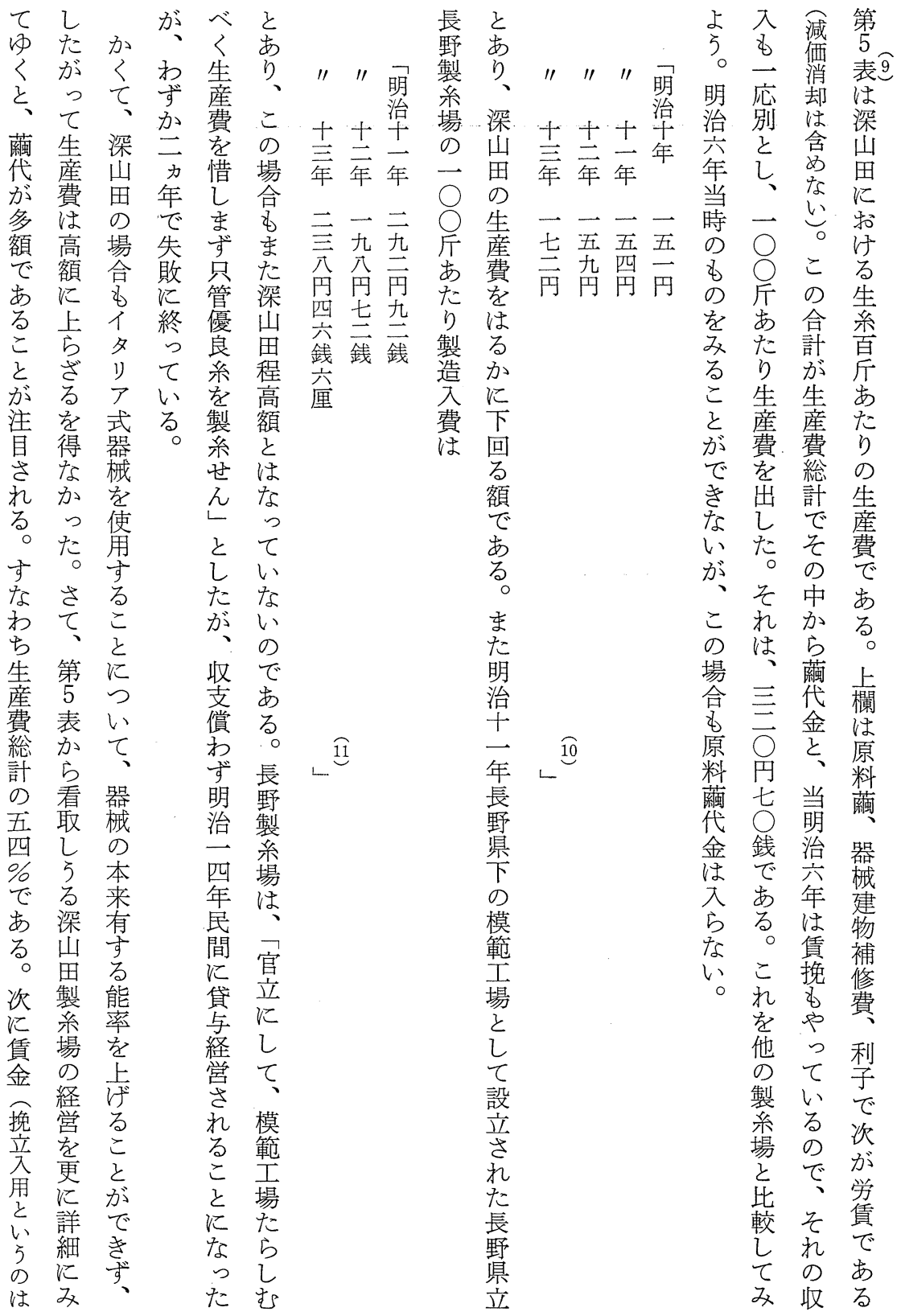


第 6 表 明治 6 年賃挽ならびに道具貸

\begin{tabular}{|c|c|c|c|c|c|}
\hline 村 & 賃 & 并 小物 貸 & 共 & \multicolumn{2}{|c|}{ 松本賃挽并小物貸共 } \\
\hline $90 \underset{7 \text { 個 } 8 \text { 分 }}{\text { 挽 }}$ & 510 円 22 銭 & 生糸 242 目長野行 & 9 円 68 銭 & 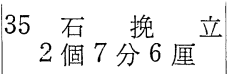 & $\begin{array}{l}180 \text { 円 } 64 \\
\text { 銭 }\end{array}$ \\
\hline 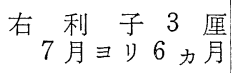 & 45 円 90 銭 & " 241 目浜 行 & 13円64銭 & 荷 & 1 円 17 鐵 \\
\hline 荷造 & 3 円50銭 & " 231 目長野行 & 13 円 24 銭 & 改 & 2 円73銭 \\
\hline 小 & 559 円 6 鈛 & " 60 目浜 行 & 2 円 40 銭 & 621 目 & 12 円 42 銭 \\
\hline 右 挽 立口銭 & & "156目古川氏行 & 6 円 24 銭 & & 96 円 96 \\
\hline $\begin{array}{l}\text { カキ・ウスマキ } \\
300\end{array}$ & 3 円 & " 30 目同所行 & 1 円 20 銭 & 右 挽立口銭 & \\
\hline 岩 崎 氏 儀 右工門 & 10円 & 新系 45 目上田行 & 2 円 & 左官小松内金 & 5 円 \\
\hline 稲 妻 $18 \mathrm{丁}$ & 8 円 25 銭 & 内上田ヨリ入 & 25 円 73 銭 & & 9 円 20 銭 \\
\hline "I 7 丁中条行 & 3 円 & 引 & 49 円 57 銭 & 駄 & 1 円15銭 \\
\hline 小センマイ三釜分 & 2 円 40 銭 & & & $\prime \prime$ & 86 銭 \\
\hline ウスマキカキ共30 & 25 銭 & & & 以 & 16 円 21 銭 \\
\hline
\end{tabular}

具六面力の資をを時物ねるしを資和器具

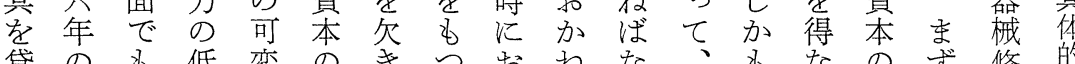

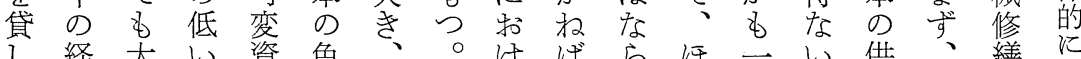

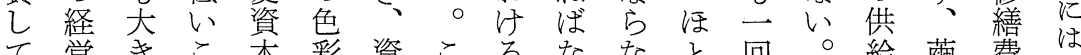

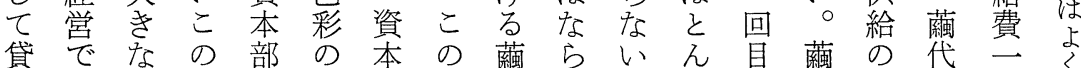

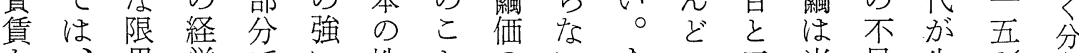
を、界営 でい性と䟚当当生\% 分 之一に注も格は高。な年回時な産、な ○一打、和製価々目一当費々

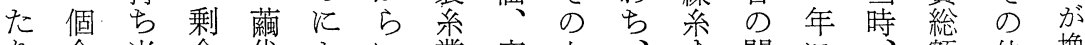
り余当余代とい業安上、导間に瀩他婏

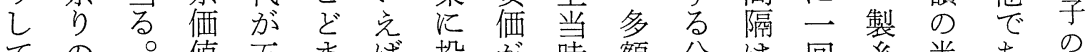
ての 0 值五 ま

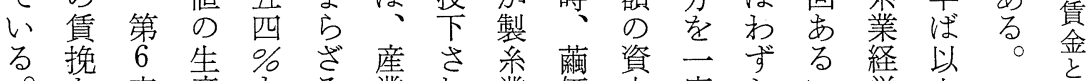

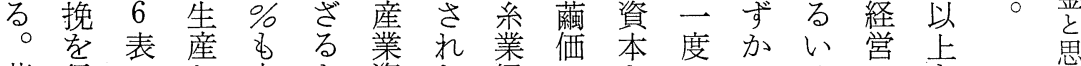

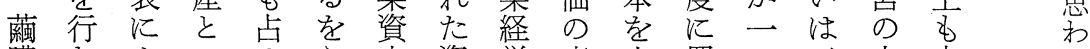

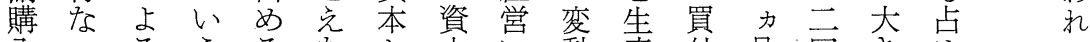
資て る る

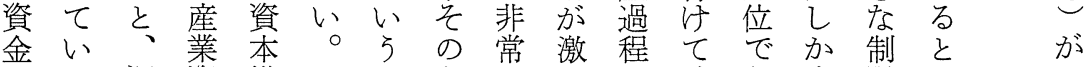

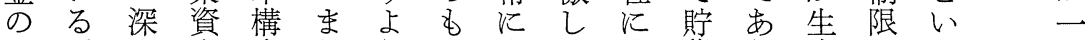
不々 足本成だり 田

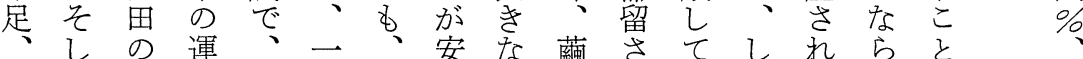

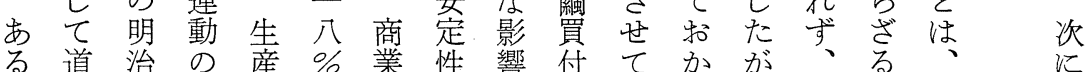


経営史 学

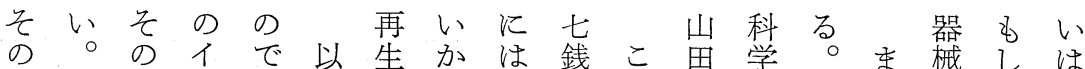
量共結夕少, 産。賃鈛こ思学前た実れ前

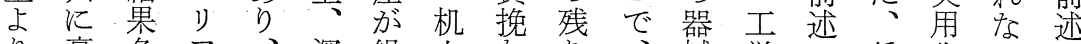
り豪多ア、深繰上なり、械学の賃化いの

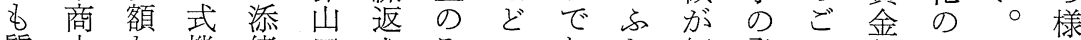
質小な 機、緒田さみの文た何発と部上いに の野生械等製れ少婏り、た回展く分でず藏 不組産の自希る計儥、び㔔度、起机の 足の費操動場 ベ算 がし第運の深近う.不

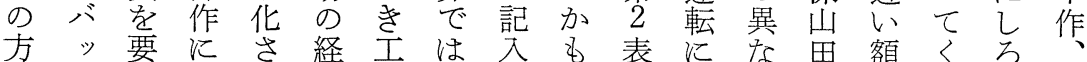

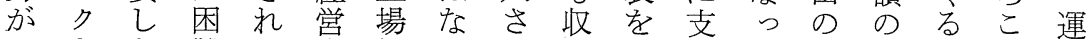
いをた難て内経かれ入文障た器器困の搬 っも学

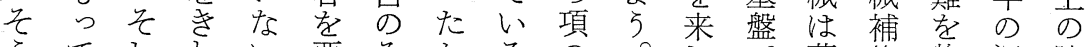

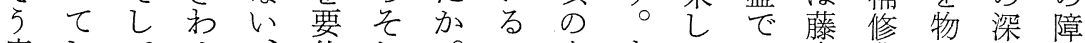
痛してめ、約れ。の生すた森費語山害

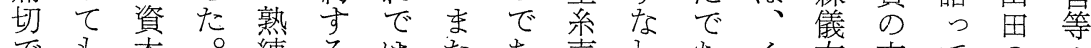

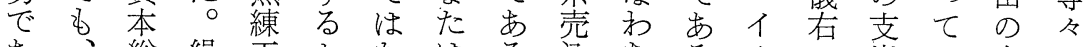

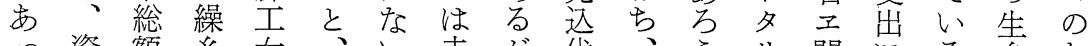

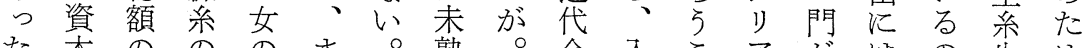
た本の の の ま 之不中能技ず、製し思金との築洋で産、

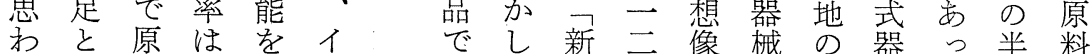
れい料上要夕夕売、糸方浓器械て分の

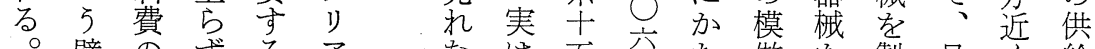

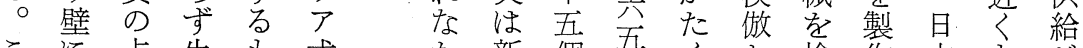
こ 占生为式 加新個五く

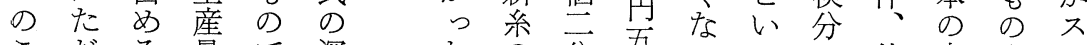
こたる量で深たの分五いっし使未糸么

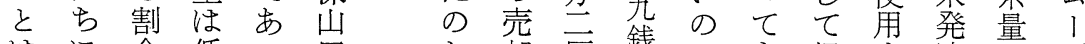

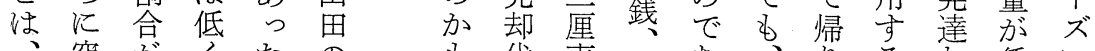

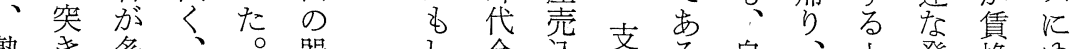

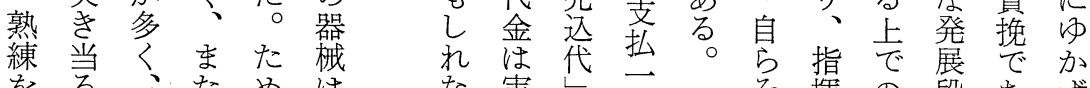

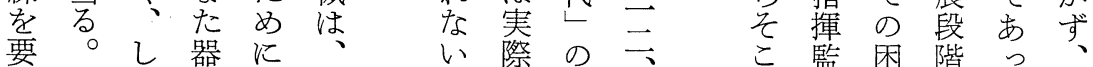
す労吕械わ的項 $\bigcirc$ に督難のた器

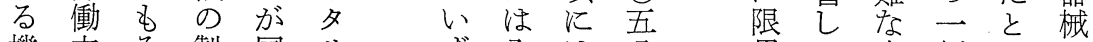
機力そ製国り 入注八界て 事側い分

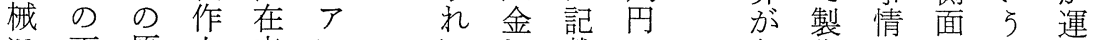
に不原上来に立載三作のとこ転

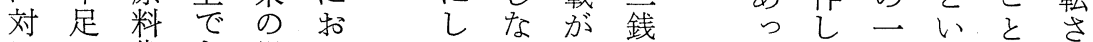

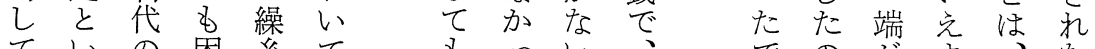

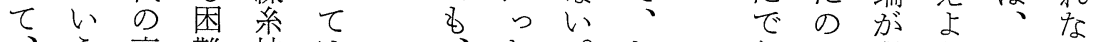

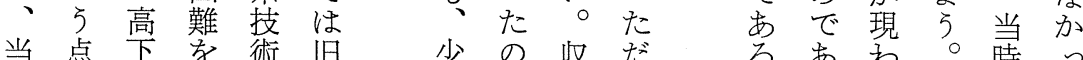

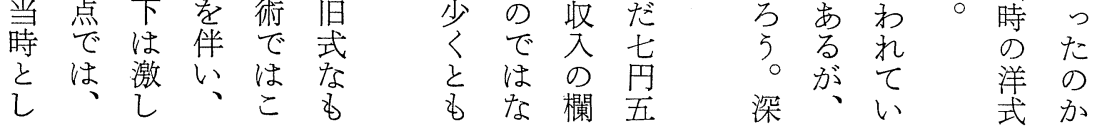


第 2 巻第 3 号

\begin{tabular}{|c|c|c|c|c|c|}
\hline $\begin{array}{l}\text { 摘 } \\
\text { 要 } \\
\text { 名 } \\
\end{array}$ & $\begin{array}{l}\text { 製糸工女 } 1 \text { 日労 } \\
\text { 働時間平均 }\end{array}$ & $\begin{array}{l}\text { 工女 } 1 \text { 人の給料 } \\
\text { 平均但食䭚共 }\end{array}$ & 贡女 1 日平均製 & $\begin{array}{l}\text { 製系 } 100 \text { 斤に対給料 } \\
\text { する費 }\end{array}$ & $\begin{array}{l}100 \text { 斤製造に対 } \\
\text { する諸費ただし } \\
\text { 系代を差引たる } \\
\text { 高 }\end{array}$ \\
\hline 伊 & 13 時 & 25 銭 & 120 多前後 & 33円33銭 & 75円 \\
\hline 仏 & 12時 & 37 銭 5 厘 & 110 多 " & 54円54銭 & 120円 \\
\hline 日 & 9 時半 & 15 銭 & 40 斥 & 60 円 & 124円 \\
\hline
\end{tabular}

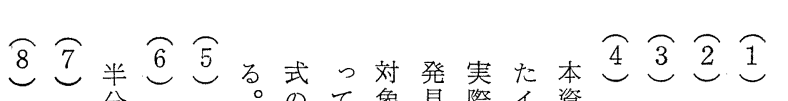

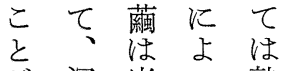
分 $\neg$ ○て象見際イ資

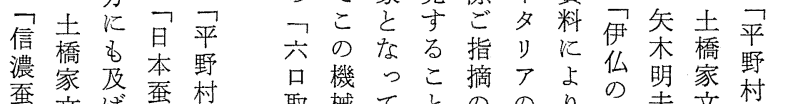

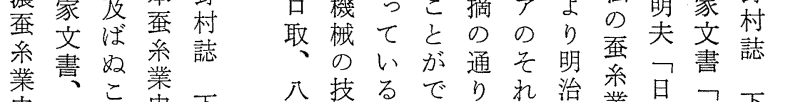

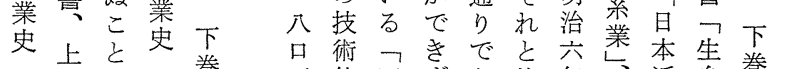

下思方二巻取的四ずあ比年、近采巻

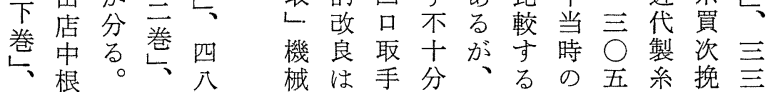

三久明五三 のイ付な筆の日頁業立五

四助治四頁改夕しが者は本少普頁

が深当り 熟

で山時て 練

き田のも工

な製流推 女

か系通察で

場过察市

たのならう

八の二九。良りとらは適の大成請

頁土六頁架了い本日当生正立等

橋年。でう資本で産五卡の

家の上製もの料には情年二表

宛調表

畫查に

簡によ

よる

当

系去はか移な態、云它

経らるた

営びの伝

責にで習

任 葤 あ工

者生る 女

の 産。の

土のし 数

橋 機 か が

家 構 \& 少

で无深

はは山

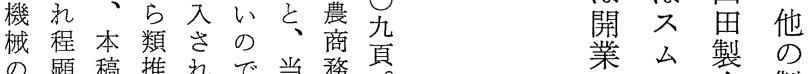

の顕稿推れで当務頁。

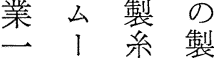

技著でせたは時省

術でもざ忌なか

年 ズ場 糸

改なべを種か大抒

半なの、工

に供、場

良かた得の、正一乙給当に

リ良かっごなると初言

の主たとかのい年付

製軸のくっのう亦記

系だでイたイ石でし

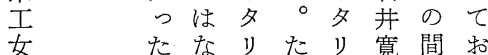

ののいアだア治急き

生でかで、で氏速た

産は。もこののない

なむ旧の生ご技。

飞次式資産指術本

日 かろな料力摘的稿

本々自もでのを改脱

の思動の比資受良稿

場わ接で較料けを後

合机尾あのをたる

てが時引

以ぎと究

後なてか

のいはれ

経、邑て

営 等 大困

の々祘

方で 経

途営と

をるにい

見。必 万

出か 要 訴 


\section{経営史学}

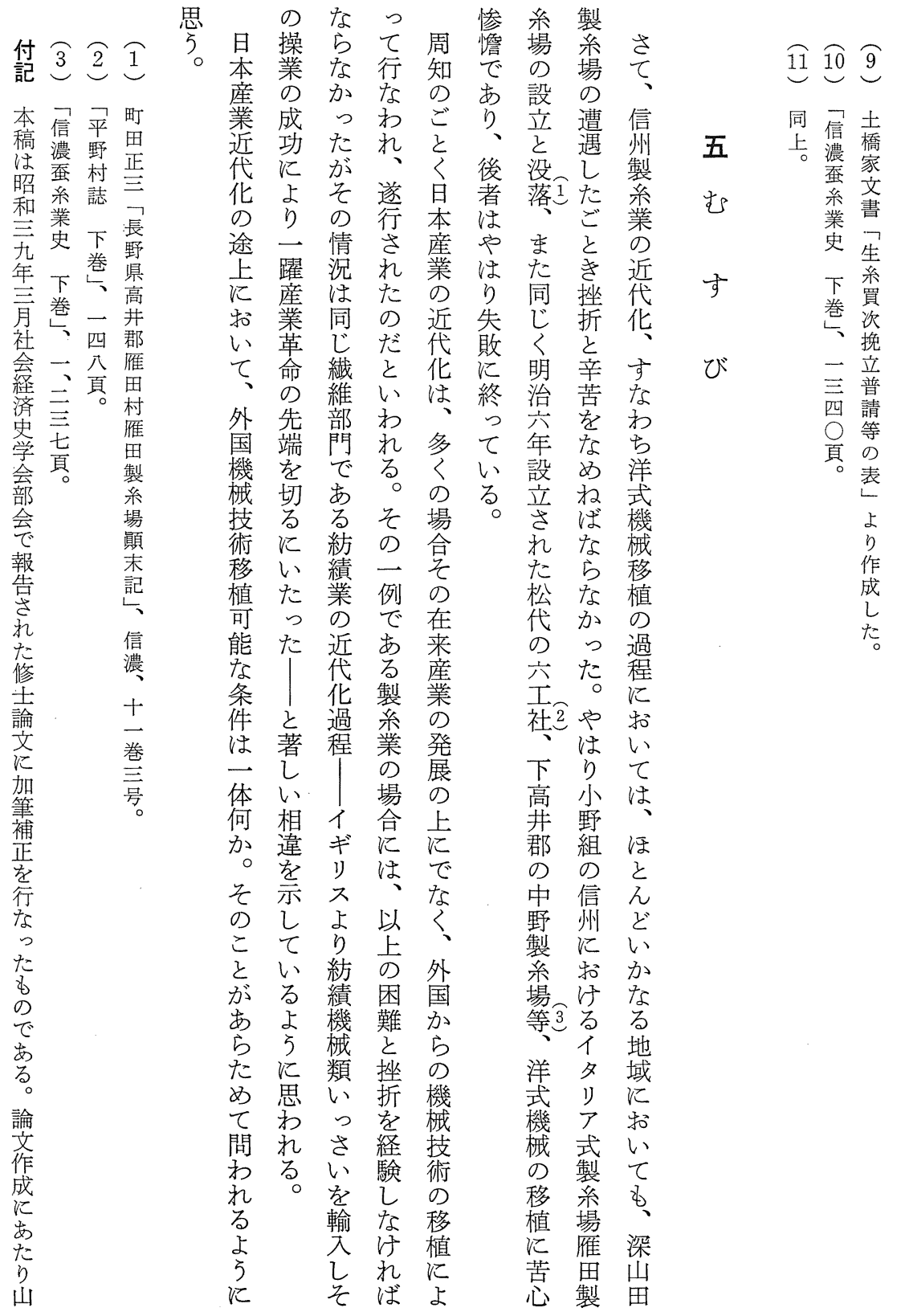


第 2 巻第 3 号

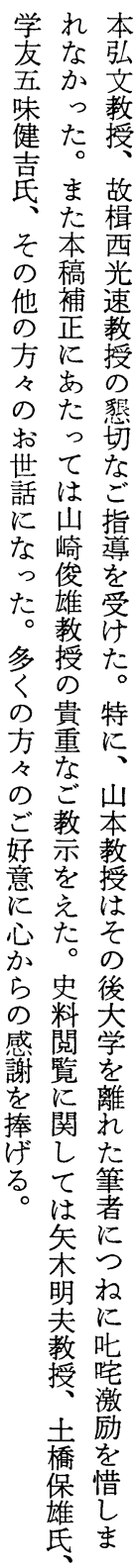




\title{
Miyamada Silk Reeling Works of the Ono Company
}

- Case of introducing foreign machines-

\author{
by \\ Hideko Nakamura \\ Tokyo Institute of Technology
}

Raw silk was one of the major items of Japanese export at the beginning of Meiji period and the Italian and French machines were introduced into Japan for the purpose of modernizing the silk reeling industry. The Ono Company started to operate a large scale reeling machines of Italian type at its Miyamada Works in 1872. But on account of the lack of skill needed for handling the sophisticated machine, the output was small and the cost of production was inevitably quite high. Unstable supply of cocoon was another source of trouble for the Miyamada Works which eventually fell into financial difficulties in 1874.

Almost all the silk reeling works of Western model had to suffer the same kind of difficulties. But the cotton industry, another textile industry that had introduced foreign machines aggressively almost from England, had achieved a brilliant success in establishing modern mills which were sufficiently competitive in international market. What was the reason for this difference between the two textile industries? 